\title{
Geophysical expression of the Leka Ophiolite, Norway, modeled from integrated gravity, magnetic and petrophysical data
}

\author{
Alexander C. Michels', Suzanne A. McEnroe ${ }^{1}$ \& Christine Fichler ${ }^{1}$ \\ ${ }^{1}$ Department of Geoscience and Petroleum, Norwegian University of Science and Technology (NTNU), 7491 Trondheim, Norway. \\ E-mail corresponding author (Alexander Michels): alexander.michels@ntnu.no
}

\begin{abstract}
The ca. 497 Ma Leka Ophiolite Complex (LOC) comprises oceanic lithosphere that formed near the margin of Laurentia in a suprasubductionzone setting. The LOC was obducted onto Laurentia in the Early Ordovician and later thrust onto Baltica during the Scandian continent-continent collisional orogeny (ca. $430 \mathrm{Ma}$ ), and now forms part of the Uppermost Allochthon. The LOC contains superb exposures of partially serpentinized mantle rocks, crustal cumulate layered series and wehrlites, sheeted dykes and pillow basalts, including exposures of the petrologic and geophysical paleo-Moho. 564 specimens were collected and measured for density, magnetic susceptibility and natural remanent magnetization. These form the constraints for three profiles forming a new 2.5D gravity and magnetic model. This is the first study of the LOC that models both gravity and magnetic data, whereas previous models were based on gravity data alone. The Bouguer-corrected anomalies express a distinct high correlating with the topographic highs in the center of the island, as well as an additional high in the southern part of the island, indicating an increasing depth of the LOC southwards. New high-resolution aeromagnetic data were used to characterize the nature of the contacts between the rock units, and the orientation of the major normal fault between the ultramafic units and the gabbro to the east. We suggest that this major fault is serpentinized, which accounts for the distinct magnetic anomaly along the trace of the fault (magnetic anomaly up to 2800 nT). Three model sections that transect the island from east to west were created. These sections indicate that the LOC has a bowl-shaped, synformal structure. Extensive serpentinization was found in samples in the uppermost portion of the LOC. The new models suggest that the deepest extent of the complex is approximately $4 \mathrm{~km}$ and that the volume of the LOC is approximately $200 \mathrm{~km}^{3}$.
\end{abstract}

Keywords: Magnetic anomalies, Gravity anomalies, Ophiolite, Magnetic properties, Densities, Tectonic processes, Serpentinization

Received 5. March 2018 / Accepted 23. March 2018 / Published online 10. June 2018

\section{Introduction}

Ophiolites have been extensively studied since first defined by Brongniart (1821). A recent overview of ophiolites is given by Dilek \& Furnes (2014). Their origin is considered to be differentiated mantle melt. Stratigraphically from top to bottom they consist of pillow lavas, sheeted dykes, gabbros, and cumulate peridotites, forming oceanic crust. Obduction of this crust forms an ophiolite. Studies of these complexes were important in the early development of the plate-tectonic theory (Dilek \& Furnes, 2011, 2014). The lithological composition of ophiolites, such as sheeted dykes adjacent to tabular intrusions of magma, and geochemical and isotopic data suggest formation related to sea-floor spreading (Dilek \& Furnes, 2014).

Ophiolites archive information from ocean basin history and evolution, and provide crucial information on mantle chemistry and structure. Ophiolites obducted onto continents may provide records in the evolution of orogenic belts (Dilek \& Furnes, 2014), and are targets for geophysical exploration because of the wealth of natural resources; i.e., gold, silver, platinum group elements, ferrous metals, and chromium that occur in

Michels, A.C., McEnroe, S.A. \& Fichler, C. 2018: Geophysical expression of the Leka Ophiolite, Norway, modeled from integrated gravity, magnetic and petrophysical data. Norwegian Journal of Geology 98, 103-125. https://dx.doi.org/10.17850/njg98-1-07. 
the ultramafic rocks of ophiolites, and large $\mathrm{Pb}-\mathrm{Zn}-\mathrm{Cu}$ deposits associated with basaltic hydrothermal systems.

Geophysical studies have been used to define the structure and history of ophiolites and to develop our understanding of crustal/mantle dynamics and tectonics. Manghnani \& Coleman (1981) used gravity measurements to refine the nappe-transport distances and the structure of the Samail Ophiolite in Oman, and the Shetland Ophiolite in northernmost Scotland was modelled with gravity as a nappe structure with a depth of $3 \mathrm{~km}$ (Flinn, 2000). In the Philippines, the Zambales Ophiolite Complex is divided into the Acoje and the Coto blocks, and Salapare et al. (2015) were the first to define the subsurface characteristics of the two ophiolites and validate the existence of a fault boundary between the two blocks. Spicer et al. (2010) using highresolution aeromagnetic maps developed a $3 \mathrm{D}$ model of the Betts Cove ophiolite complex in Newfoundland as a syncline with normal and high-angle reverse faults. Paleomagnetism was used to detect the age of a low-temperature alteration event during the midCarboniferous, that was previously unknown in the Shetland Ophiolite (Taylor, 1988), and Pozzi et al. (1984) used paleomagnetism to define the paleo-orientation and paleo-latitude of the spreading center that had created the Xigaze ophiolite in Tibet.

The island of Leka, $3.5 \mathrm{~km}$ off the coast of central Norway, comprises the Leka Ophiolite Complex (LOC). The island is the National Geological Monument of Norway and part of the Trollfjell Geopark. It is one of the best exposed and most complete ophiolite complexes in northern Europe, containing all components of an ophiolite (Furnes et al., 1988, 1992), but not in a continuous sequence due to faulting. $\mathrm{U}-\mathrm{Pb}$ zircon dating of a trondjemite with an age of $497 \pm 2 \mathrm{Ma}$ (Dunning \& Pedersen, 1988) indicates that the ophiolite age is higher. Formation of the LOC is attributed to sea-floor spreading in a suprasubduction-zone setting (Furnes et al., 1988), similar to other ophiolites in the Scandinavian Caledonides (Pedersen et al., 1988; Slagstad et al., 2014).

Here, we present a combined model of gravity and total magnetic intensity (TMI) data using new high-resolution aeromagnetic data and gravity acquired by the Geological Survey of Norway (NGU). We constrain the model parameters with new petrophysical properties from 564 samples, reported here, and from previous work (Sindre \& Pedersen, 1990). We compare our model with previous models that were based solely on gravity, including a $2 \mathrm{D}$ gravity model by Sindre \& Pedersen (1990) and a 3D gravity inversion model by Titus et al. (2002).

\section{Geological background}

The Leka Ophiolite Complex (LOC) is exposed on the island of Leka in Trøndelag, central Norway (Fig. 1). It is situated in the Uppermost Allochthon of the Norwegian Caledonides as part of the Helgeland Nappe Complex (Dunning \& Pedersen, 1988; Bucher-Nurminen, 1991; McArthur et al., 2014). According to Dunning \& Pedersen (1988), the trondhjemite (plagiogranite; Fig. 1) of the upper plutonic zone of the LOC yielded a $\mathrm{U}-\mathrm{Pb}$ zircon age of $497 \pm 2 \mathrm{Ma}$. This age suggests that the LOC formed in the Late Cambrian. Recently, O'Driscoll et al. (2015) reported two new ages for the LOC using Re-Os isotopes from a chromite layer ( $485 \pm 32 \mathrm{Ma})$ and from pyroxenites (589 $\pm 2 \mathrm{Ma})$. The younger age, with a large error, overlaps the more precise $\mathrm{U}-\mathrm{Pb}$ zircon age.

The LOC was obducted northwestward onto Laurentia about 30 Myr before the Taconian-Grampian orogeny (Pedersen et al., 1988; Titus et al., 2002; Hollocher et al., 2016). Later, during the Scandian orogeny, the LOC was transferred onto Baltica as part of the Uppermost Allochthon (Dunning \& Pedersen, 1988). The rocks at the base of the LOC are assumed to be lower amphibolitefacies Baltican basement gneisses of the Northern Vestranden region (Furnes et al., 1988; Schouenborg, 1988; Sturt \& Ramsay, 1994). Though only exposed on the mainland east of Leka, the contact is considered to be defined by the late-Scandian Kollstraumen detachment ( 395 Ma; Nordgulen et al., 2002).

All the components of a typical ophiolite are exposed in the LOC, though not as one continuous section, but as several tectonically separated blocks. This includes the depleted upper mantle, mainly as deformed harzburgites, stratigraphically overlain by crustal ultramafic cumulates, layered gabbros, basaltic dykes and pillow lavas (Prestvik, 1980; Furnes et al., 1988). During, or after the obduction onto Laurentia $(\sim 480 \mathrm{Ma})$ and continuing into the Scandian orogeny, the LOC's mafic and ultramafic rocks underwent moderate-scale ductile deformation leading to folding and the formation of an open synform (Dunning \& Pedersen, 1988; Titus et al., 2002; Maaløe, 2005). Later, the LOC was subjected to brittle deformation leading to the formation of two sets of faults. The NE-SW-trending faults are longer and more apparent than the NWSE-trending faults (Titus et al., 2002).

The mantle material is composed predominantly of harzburgite (Fig. 2A, B) and is exposed mainly in two belts on the island's northwestern side. It is composed of olivine, primary and secondary clinopyroxene, Cr-spinel, ferritchromite, magnetite, serpentine, brucite and clinochlore (Iyer et al., 2008). The tectonic history of the ophiolite resulted in a contact of harzburgite against the overlying gabbro (main fault contact in Fig. 1). In the northeastern harzburgite unit the petrological paleo-Moho can be observed as the contact between the lower-crustal cumulate peridotites (layered series) and 

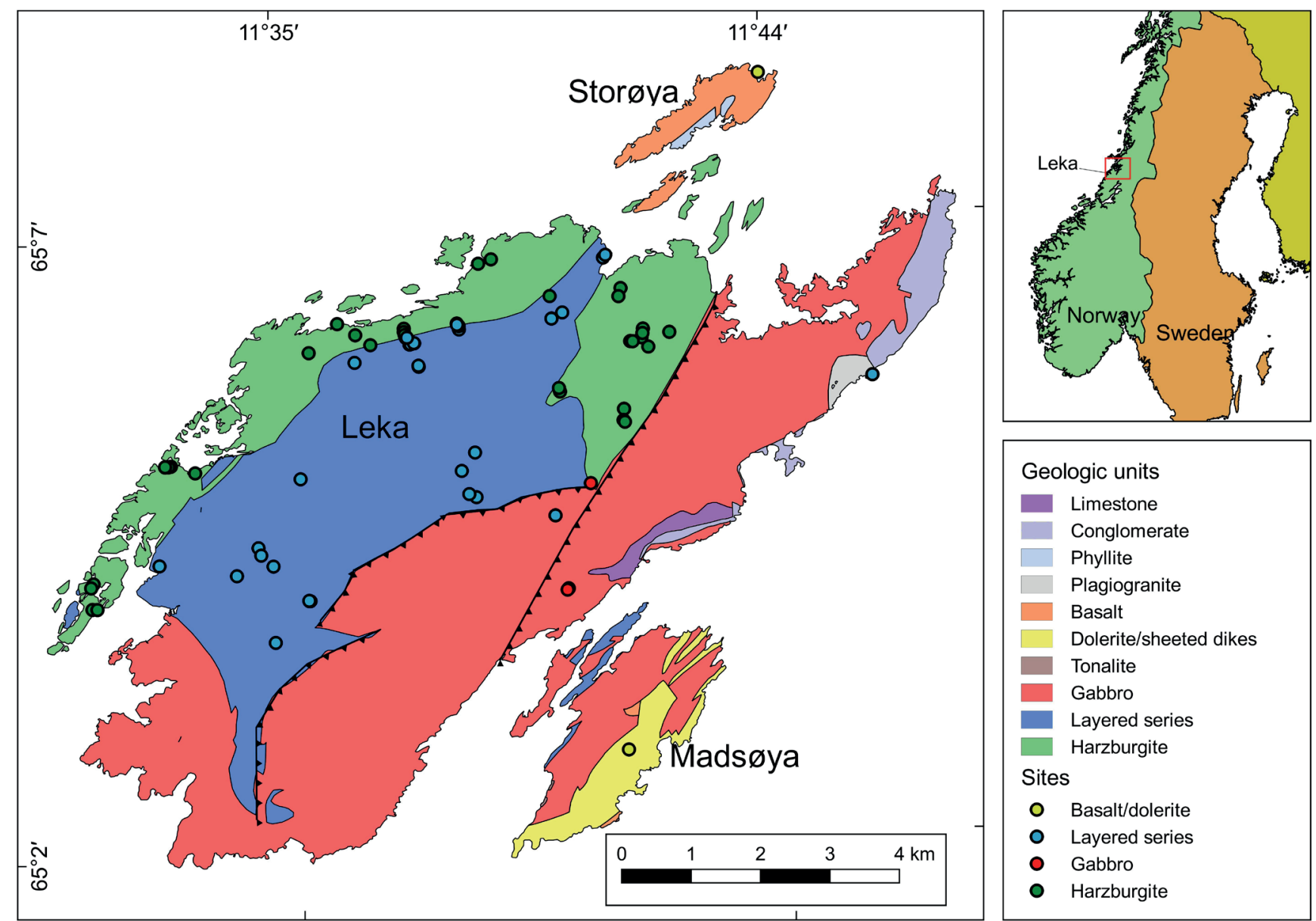

Figure 1. Geologic map of Leka and surrounding islands along with its location in Norway (red square). The island of Leka is composed mainly of three rock units: gabbro (red), layered series (blue) and harzburgite (green). The gabbro is separated from the ultramafic rocks by a normal fault. The contact between the LOC and the country rock is not exposed and lies under the sea. Geology shapefiles are modified from the NGU database (Pedersen et al., 2011). Sample site locations are shown as circles.

the overlying mantle harzburgites. Dunite lenses and sheets occur within the harzburgite rock (Albrektsen et al., 1991; Maaløe, 2005).

Above the petrological paleo-Moho lie the crustal ultramafic cumulates, a sequence of layered websteritewehrlite and dunite and will be referred to as the layered series' (Fig. 2C, D) following Furnes et al. (1988). The dunites in the layered series are primarily composed of olivine, serpentine, brucite, $\mathrm{Cr}$-spinel and magnetite. The wehrlites differ from these dunites and contain primary and secondary clinopyroxene, olivine, serpentine, brucite, clinochlore, $\mathrm{Cr}-\mathrm{Al}$ spinel, ferritchromite and magnetite (Iyer et al., 2008).

The gabbro varies texturally from fine grained to pegmatitic (Pedersen \& Furnes, 1991) and has rare earth element patterns typical for gabbroic rocks from ophiolite complexes (Prestvik \& Roaldset, 1978). The gabbro is well exposed to the east and south of the layered series. The contact between the southern gabbro area and the layered series contains a mixed unit of layered gabbro and layered series which is not included in the geological map (Fig. 1). The eastern contact is mapped as a fault and there is no obvious interlayered sequence of layered series and gabbro (Fig. 2E, F). Farther to the north, the gabbro is terminated at a fault contact with the harzburgite.

The basalts are exposed (Fig. 2G, H) on the islands of Madsøya and Storøya as pillow basalts. Basalts on Madsøya occur as non-vesicular pillow basalts along with bedded cherts that act as screens between basaltic dykes, or are surrounded by microgabbro (Furnes et al., 1988). On Storøya, the basalts occur either as pillow basalts or as breccia and massive lava flows. The entire Storøya basalt sequence is more than $600 \mathrm{~m}$ thick and is overlain by sediments including black shales (phyllite in Fig. 1; Furnes et al., 1988). There is no visible contact between these basalts and the rest of the ophiolite sequence, but Prestvik (1985) interpreted the basalts to be part of the LOC based on the presence of tectonic contacts with units of the LOC on skerries in between Storøya and Leka, and also because the basalts formed in an oceanic environment (Prestvik, 1985).

The basalts show evidence of greenschist-facies metamorphism, and the gabbro and mantle rocks contain amphibolite-facies minerals (Prestvik, 1972, 1980; 


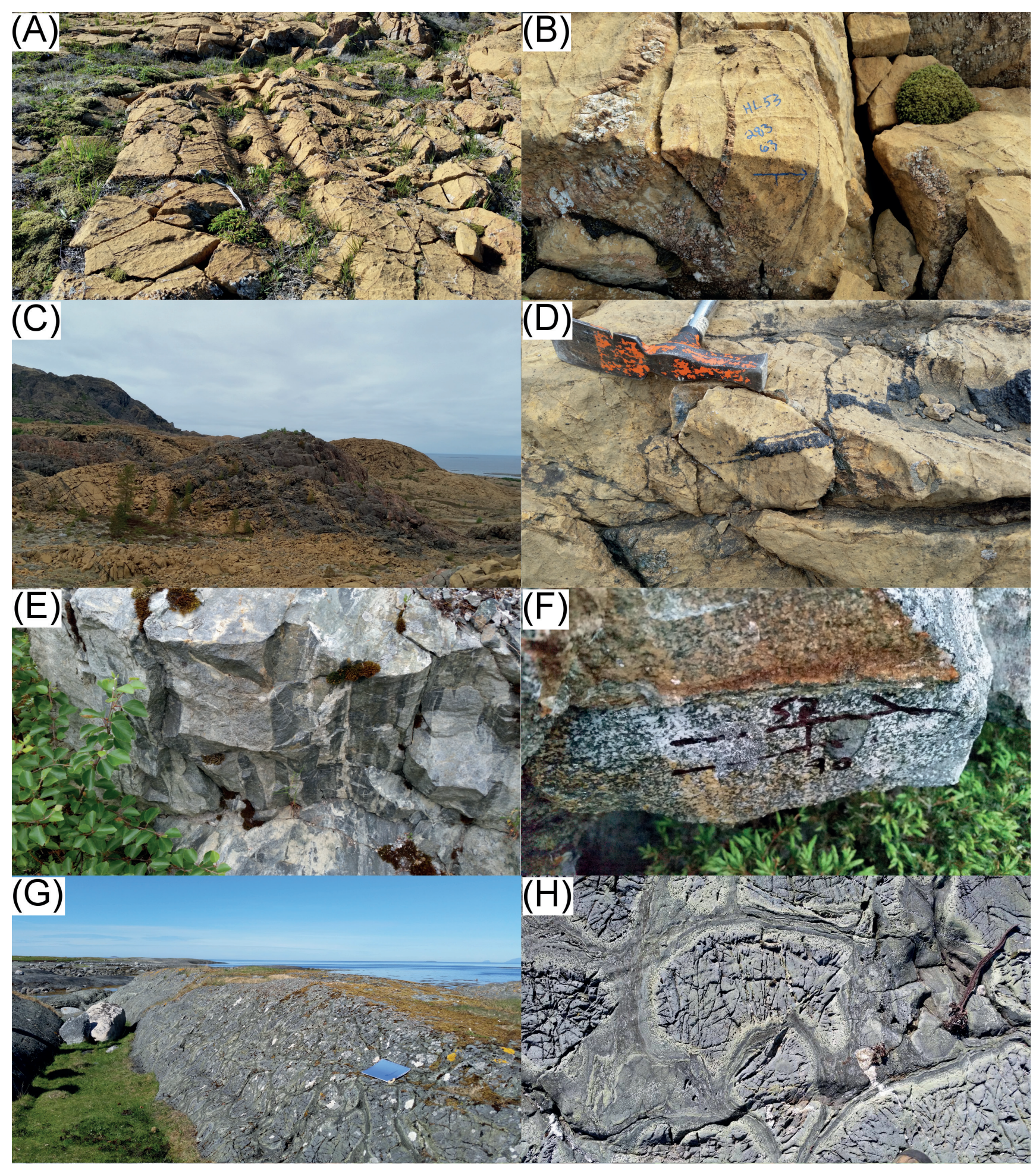

Figure 2. (A) Harzburgite outcrop with possible erosional features. (B) Harzburgite block from the northwestern shore (site 54). (C) Layered series outcrop in the center of the island, showing layered cumulates (site 24). (D) Layered series with chromite veins. (E-F) Gabbro outcrops near the eastern shore (site 74). (G) Pillow basalt outcrop on the island of Storøya (site 75). (H) Close-up of pillow basalt.

Furnes et al., 1988; Bucher-Nurminen, 1991; Bjerga et al., 2015). Metamorphism likely occurred during the Early Ordovician obduction event and/or during the Scandian orogeny, during which some of the ultramafic rocks received an antigorite overprint (Bucher-Nurminen,
1991) resulting in an increase in magnetite content and concomitant decrease in density. The increase in magnetite content will result in enhanced magnetic anomalies, and the decrease in density in gravity lows compared with unaltered ultramafic rocks. These are 
common features of serpentinized oceanic lithosphere, as has been widely noted by many authors (see Blakely et al., 2005).

\section{Methods}

\section{Fieldwork}

Samples from 76 site localities were collected across the LOC and from each of the rock units (Fig. 1). Thirtythree sites were drilled using a portable gasolinepowered drill with a diamond-tipped drill bit of $2.54 \mathrm{~cm}$ diameter and oriented with a magnetic compass in the field. Approximately six to eight cores were taken at each field site. At localities where there was an obvious color change in the sequence, more cores were drilled. Fortythree sites were collected as oriented blocks and later drilled in the lab at NTNU using a hydraulic coring drill press. Cores were cut to avoid surface weathering.

\section{Density}

Core specimens were soaked overnight in deionized water, towel dried and their mass and densities were calculated using a Mettler Toledo ML104 scale. The samples' densities were used to calculate an overall site mean density. Using density and mass, each specimen's volume was calculated for the purpose of volume normalization of susceptibility and natural remanent magnetization (NRM).

\section{NRM}

NRM intensity and directions were measured using the AGICO JR-6 Spinner magnetometer. For each site, NRM values of 6 to 8 cores were averaged using the vector NRM, after removing any samples where values were outside two orders of magnitude from the rest of the site. The vector NRM takes the intensity into account and is a more accurate parameter for the purposes of modeling than the mean scalar NRM value.

\section{Susceptibility}

Magnetic susceptibility was measured for each sample using a SI2B susceptibility meter operating with a field of $80 \mathrm{~A} / \mathrm{m}$. Magnetic susceptibility values were averaged to calculate a mean value for each site, excluding outliers that were outside two orders of magnitude from the rest of the site values. All data are given in Table 1.

\section{Laboratory results}

\author{
Magnetic property data
}

The values used in the model are based on the range of values for the different rock types and geographic localities. The resulting site averages for density, magnetic susceptibility, NRM intensity and direction are shown in Table 1.

The 242 layered series samples had NRM values ranging from ca. 0.01 to $34 \mathrm{~A} / \mathrm{m}$, with an average of $3.3 \mathrm{~A} / \mathrm{m}$. Two sites ( 3 and 5) have very high average NRM values of 20 and $22 \mathrm{~A} / \mathrm{m}$, respectively. Site 3 is located near the major fault. When these two sites are removed, the remaining samples (222) have an average NRM of $1.8 \mathrm{~A} / \mathrm{m}$. Nine sites (59 samples) are from areas where there are chromite-rich veins and these samples show consistently lower NRM values, with an average of $0.83 \mathrm{~A} / \mathrm{m}$.

The average susceptibility value of the layered series is 0.0367 (SI) with a range from 0.0004 to 0.2096 (SI). Removing the samples with very high NRM values, the average susceptibility is 0.0274 SI with a range from 0.0004 to 0.1000 SI. By removing the samples that are rich in chromite the average susceptibility for the layered series rocks increases to $0.0472 \mathrm{SI}$.

Samples from the harzburgite are generally magnetically weaker, with an intensity range from $<0.1 \mathrm{~A} / \mathrm{m}$ to 18 $\mathrm{A} / \mathrm{m}$, with an outlier of $127 \mathrm{~A} / \mathrm{m}$ and an average of 2.5 $\mathrm{A} / \mathrm{m}$ from 252 specimens. NRM intensities are $<4$ $\mathrm{A} / \mathrm{m}$ for $90 \%$ of the harzburgite samples. The average susceptibility value is 0.0282 , with a range from 0.0003 to 0.0687 (SI). Removing samples that have intensities over $10 \mathrm{~A} / \mathrm{m}$ leaves 240 specimens with an average NRM intensity of $1.4 \mathrm{~A} / \mathrm{m}$ and an average susceptibility of 0.0276 (SI), ranging from 0.0003 to 0.0687 (SI).

The gabbro samples have an average susceptibility of 0.0005 (SI). NRM directions were scattered and intensity values had an average of $0.032 \mathrm{~A} / \mathrm{m}$. These values are low for a typical gabbro (Clark, 1999). Although 24 samples from the gabbro constitute a relatively small sample set, the aeromagnetic data show that the TMI over the gabbroic rock unit is closer to background values compared to the other rock units on Leka. The TMI of the gabbro supports the interpretation that the very low NRM and susceptibility values, measured from the limited sample collection, are representative for the gabbro. Petrographic investigations showed little or no magnetite in thin-sections and the dominant oxide was ilmenite without observable hematite exsolution. Oceanic gabbro commonly contains magnetite, but here ilmenite is the dominant oxide, and little to no magnetite is observed in thin-sections in agreement with the very low susceptibility values. 
Table 1. The petrophysical properties by site. $n$ - number of samples used for calculating site average, NRM declination and inclination are in geographic coordinates calculated from a vector NRM. Jr - NRM intensity. Ji - induced magnetization. Q - Jr/Ji. * - Sites with high magnetic properties on one or more samples. \# - Site has negative inclination. 'c'-sites that have samples with chromite. 'f' - sites that occur near the fault between the gabbro and the ultramafic rocks. ' $w$ ' - indicates the harzburgite site is on the western exposure of the LOC as seen in Fig. 1. ' $e$ '- indicates the harzburgite site is on the eastern side of the LOC. Arithmetic averages are calculated from samples and for each rock unit.

\begin{tabular}{|c|c|c|c|c|c|c|c|c|}
\hline Site & $N$ & $\begin{array}{c}\text { NRM Dec } \\
\left({ }^{\circ}\right)\end{array}$ & $\begin{array}{c}\text { NRM Inc } \\
\left({ }^{\circ}\right)\end{array}$ & $J r(A / m)$ & $\begin{array}{c}\text { Susceptibility } \\
\text { (SI) }\end{array}$ & $J i(A / m)$ & $Q$ & $\begin{array}{r}\text { Density } \\
\left(k g / m^{3}\right)\end{array}$ \\
\hline \multicolumn{9}{|c|}{ Layered series } \\
\hline 1 & 7 & 343.6 & 76.6 & 8.08 & 0.084288 & 3.50 & 2.3 & 2863 \\
\hline 2 & 6 & 49.0 & 61.1 & 0.58 & 0.006697 & 0.30 & 2.1 & 3003 \\
\hline $3^{\star} \mathrm{f}$ & 9 & 334.8 & 64.0 & 19.70 & 0.209576 & 8.70 & 2.3 & 2734 \\
\hline 4 & 4 & 122.5 & 57.0 & 7.69 & 0.067593 & 2.81 & 2.7 & 2975 \\
\hline $5^{*}$ & 9 & 336.6 & 32.9 & 21.52 & 0.077703 & 3.23 & 6.7 & 2761 \\
\hline 6 & 7 & 26.1 & 34.9 & 2.33 & 0.038185 & 1.59 & 1.5 & 2797 \\
\hline $7 f$ & 7 & 100.0 & 84.6 & 4.38 & 0.096738 & 4.02 & 1.1 & 2756 \\
\hline 8 & 2 & 57.7 & 55.6 & 0.60 & 0.013818 & 0.57 & 1.1 & 2746 \\
\hline 9 & 5 & 35.0 & 52.7 & 4.15 & 0.076603 & 3.18 & 1.3 & 2695 \\
\hline 10 & 6 & 134.1 & 86.5 & 0.06 & 0.002148 & 0.09 & 0.6 & 2771 \\
\hline 11 & 7 & 19.1 & 48.2 & 1.41 & 0.024007 & 1.00 & 1.4 & 2956 \\
\hline $12 \mathrm{c}$ & 11 & 24.7 & 65.9 & 1.65 & 0.031057 & 1.29 & 1.3 & 3035 \\
\hline 13 & 4 & 346.7 & 48.2 & 1.48 & 0.013740 & 0.57 & 2.6 & 2955 \\
\hline 14 & 9 & 10.9 & 34.8 & 5.00 & 0.086298 & 3.58 & 1.4 & 2773 \\
\hline $15 c$ & 5 & 41.2 & 6.0 & 0.73 & 0.013891 & 0.58 & 1.3 & 3210 \\
\hline $16 c$ & 8 & 56.7 & 41.0 & 0.60 & 0.007301 & 0.30 & 2.0 & 3088 \\
\hline 17 & 9 & 209.2 & 51.4 & 0.08 & 0.000380 & 0.02 & 4.9 & 2684 \\
\hline 18 & 7 & 289.5 & 36.4 & 0.73 & 0.015004 & 0.62 & 1.2 & 2789 \\
\hline 19 & 7 & 315.5 & 78.3 & 3.95 & 0.053005 & 2.20 & 1.8 & 2801 \\
\hline 20 & 11 & 157.3 & 6.3 & 0.44 & 0.012319 & 0.51 & 0.9 & 2833 \\
\hline 21 & 11 & 137.0 & 30.2 & 0.20 & 0.008194 & 0.34 & 0.6 & 2859 \\
\hline 22 & 4 & 163.9 & 75.5 & 0.80 & 0.013339 & 0.55 & 1.4 & 2795 \\
\hline $23 \mathrm{c}$ & 5 & 230.5 & 49.9 & 1.22 & 0.025854 & 1.07 & 1.1 & 3133 \\
\hline $24 c$ & 6 & 68.9 & 58.7 & 1.29 & 0.006406 & 0.27 & 4.8 & 3179 \\
\hline 25 & 4 & 331.5 & 62.8 & 0.31 & 0.012588 & 0.52 & 0.5 & 2904 \\
\hline $26 \mathrm{c}$ & 6 & 321.5 & 43.6 & 0.30 & 0.006332 & 0.26 & 1.1 & 3194 \\
\hline $27 \mathrm{c}$ & 8 & 355.4 & 70.6 & 0.71 & 0.003576 & 0.15 & 4.8 & 3259 \\
\hline $28 \mathrm{c}$ & 9 & 357.6 & 57.7 & 0.32 & 0.003607 & 0.15 & 2.1 & 3291 \\
\hline $29 c$ & 6 & 266.9 & 84.7 & 0.67 & 0.003926 & 0.16 & 4.1 & 3434 \\
\hline 30 & 10 & 342.5 & 47.9 & 0.26 & 0.004814 & 0.20 & 1.3 & 2970 \\
\hline 31 & 5 & 57.1 & 69.9 & 3.02 & 0.099652 & 4.14 & 0.7 & 2917 \\
\hline 32 & 5 & 163.6 & 46.8 & 2.27 & 0.051256 & 2.13 & 1.1 & 2958 \\
\hline 33 & 10 & 7.5 & 60.8 & 4.67 & 0.072291 & 3.00 & 1.6 & 2653 \\
\hline Average & 242 & 353.7 & 60.2 & 3.37 & 0.037718 & 1.56 & 2.2 & 2939 \\
\hline Avg. w/o c & 183 & 352.8 & 59.4 & 4.20 & 0.047162 & 1.95 & 2.1 & 2834 \\
\hline Avg. w/o* & 222 & 22.6 & 69.1 & 1.83 & 0.028788 & 1.19 & 1.5 & 2955 \\
\hline Site avg. & 242 & 356.6 & 64.7 & 3.06 & 0.037617 & 1.56 & 2.0 & 2922 \\
\hline \multicolumn{9}{|c|}{ Harzburgites } \\
\hline $34 \mathrm{w}$ & 9 & 359.3 & 72.3 & 0.35 & 0.00636 & 0.26 & 0.3 & 2920 \\
\hline $35 \mathrm{e}$ & 11 & 99.9 & 62.6 & 1.63 & 0.025082 & 1.04 & 0.6 & 2707 \\
\hline $36 \mathrm{e}$ & 8 & 59.7 & 56.8 & 2.36 & 0.041396 & 1.72 & 1.4 & 2699 \\
\hline $37 \mathrm{e}$ & 3 & 331.4 & 83.8 & 2.85 & 0.033568 & 1.39 & 2.0 & 2808 \\
\hline $38 \mathrm{e}$ & 9 & 113.6 & 54.5 & 0.64 & 0.019551 & 0.81 & 0.8 & 2745 \\
\hline $39 \mathrm{e}$ & 3 & 88.4 & 77.1 & 1.97 & 0.064553 & 2.68 & 0.7 & 2728 \\
\hline
\end{tabular}




\begin{tabular}{|c|c|c|c|c|c|c|c|c|}
\hline Site & $N$ & $\begin{array}{c}\text { NRM Dec } \\
\left({ }^{\circ}\right)\end{array}$ & $\begin{array}{c}\text { NRM Inc } \\
\left({ }^{\circ}\right)\end{array}$ & $J r(A / m)$ & $\begin{array}{l}\text { Susceptibility } \\
\text { (SI) }\end{array}$ & $J i(A / m)$ & $Q$ & $\begin{array}{l}\text { Density } \\
\left(\mathrm{kg} / \mathrm{m}^{3}\right)\end{array}$ \\
\hline $40 \mathrm{e}$ & 4 & 177.2 & 71.4 & 2.55 & 0.062650 & 2.60 & 1.0 & 2719 \\
\hline $41 \mathrm{w}$ & 5 & 309.5 & 68.7 & 0.18 & 0.004666 & 0.19 & 0.9 & 2802 \\
\hline $42 w$ & 5 & 240.9 & 44.2 & 0.003 & 0.000311 & 0.01 & 0.2 & 2711 \\
\hline $43 \mathrm{w}$ & 6 & 28.5 & 67.4 & 1.58 & 0.019402 & 0.81 & 2.0 & 2737 \\
\hline $44 \mathrm{w}$ & 6 & 88.3 & 42.7 & 4.54 & 0.068740 & 2.85 & 1.6 & 2766 \\
\hline $45 \mathrm{e}$ & 5 & 325.6 & 70.4 & 1.78 & 0.038418 & 1.59 & 1.1 & 2693 \\
\hline $46 w$ & 7 & 80.3 & 70.7 & 1.36 & 0.062852 & 2.61 & 0.5 & 2875 \\
\hline $47 \mathrm{w}$ & 6 & 298.4 & 69.4 & 5.71 & 0.057002 & 2.37 & 2.4 & 2939 \\
\hline $48 w$ & 4 & 73.8 & 81.6 & 2.68 & 0.058296 & 2.42 & 1.1 & 2903 \\
\hline $49 w$ & 6 & 50.2 & 35.8 & 0.85 & 0.019528 & 0.81 & 1.1 & 2697 \\
\hline $50 \mathrm{w}$ & 7 & 336.2 & 70.4 & 0.62 & 0.004734 & 0.20 & 3.1 & 2821 \\
\hline $51 \mathrm{w}$ & 7 & 329.4 & 51.4 & 0.27 & 0.004749 & 0.20 & 1.4 & 2776 \\
\hline $52 \mathrm{w}$ & 11 & 197.6 & 66.3 & 0.42 & 0.007390 & 0.31 & 1.5 & 2732 \\
\hline $53 w$ & 9 & 8.3 & 57.5 & 2.34 & 0.044189 & 1.83 & 1.3 & 2933 \\
\hline $54 w$ & 9 & 32.6 & 64.4 & 0.96 & 0.017735 & 0.74 & 1.3 & 2680 \\
\hline $55 \mathrm{w}$ & 9 & 279.1 & 0.6 & 0.78 & 0.005270 & 0.22 & 3.6 & 2791 \\
\hline $56 w$ & 3 & 344.1 & 21.3 & 1.33 & 0.018134 & 0.75 & 1.8 & 2803 \\
\hline $57 \mathrm{e}$ & 5 & 80.1 & 52.4 & 1.77 & 0.044692 & 1.86 & 1.0 & 2764 \\
\hline $58 \mathrm{e}$ & 6 & 32.7 & 69.8 & 1.39 & 0.040722 & 1.69 & 0.8 & 2763 \\
\hline $59 w$ & 9 & 41.7 & 71.8 & 1.53 & 0.030316 & 1.26 & 1.2 & 2720 \\
\hline $60 w$ & 6 & 13.6 & 66.8 & 0.75 & 0.023449 & 0.97 & 0.8 & 2758 \\
\hline $61 \mathrm{e}$ & 4 & 247 & 79.5 & 0.66 & 0.024718 & 1.03 & 0.6 & 2745 \\
\hline $62 \mathrm{e}$ & 7 & 229 & 60.8 & 0.57 & 0.014705 & 0.61 & 0.9 & 2784 \\
\hline $63 \mathrm{w}$ & 7 & 189.7 & 77.0 & 3.30 & 0.031202 & 1.30 & 2.5 & 2747 \\
\hline $64 w$ & 13 & 335.5 & 55.7 & 0.36 & 0.010681 & 0.44 & 0.8 & 2739 \\
\hline $65 \mathrm{w}$ & 7 & 168.7 & 37.6 & 1.63 & 0.037442 & 1.55 & 1.1 & 2842 \\
\hline $66 \mathrm{e}$ & 6 & 54.6 & 39.3 & 1.73 & 0.042299 & 1.76 & 1.0 & 2751 \\
\hline $67^{*} \mathrm{e}$ & 7 & 221.5 & 19.8 & 8.34 & 0.030874 & 1.28 & 6.5 & 2780 \\
\hline $68 \mathrm{e}$ & 6 & 113.7 & 76.6 & 0.56 & 0.035856 & 1.49 & 0.4 & 2841 \\
\hline $69^{\star} \# \mathrm{e}$ & 6 & 32.9 & -58.1 & 13.03 & 0.038657 & 1.60 & 8.1 & 2761 \\
\hline $70 w$ & 11 & 116.3 & 43.4 & 2.50 & 0.031503 & 1.31 & 1.9 & 3073 \\
\hline Average & 252 & 64.1 & 81.4 & 2.03 & 0.028192 & 1.16 & 1.7 & 2788 \\
\hline Avg. w/o* & 240 & 72.7 & 75.7 & 1.44 & 0.027575 & 1.14 & 1.2 & 2788 \\
\hline Site Avg. & 252 & 59.8 & 77.1 & 2.05 & 0.030316 & 1.26 & 1.6 & 2785 \\
\hline Site avg. west & 162 & 59.1 & 79.8 & 1.54 & 0.025237 & 1.04 & 1.5 & 2808 \\
\hline Site avg. east & 90 & 60.8 & 70.2 & 2.80 & 0.037766 & 1.57 & 1.9 & 2751 \\
\hline \multicolumn{9}{|l|}{ Gabbro } \\
\hline 71 & 4 & 162.2 & 63.7 & 0.01 & 0.000427 & 0.02 & 0.7 & 2944 \\
\hline $72 \mathrm{f}$ & 5 & 242.3 & 57.3 & 0.0001 & 0.000274 & 0.01 & 0.01 & 3051 \\
\hline 73 & 7 & 122.8 & 72.2 & 0.03 & 0.000725 & 0.03 & 1.1 & 3164 \\
\hline 74 & 8 & 314.5 & 73.1 & 0.06 & 0.000537 & 0.02 & 2.7 & 2918 \\
\hline Average & 24 & 205.0 & 73.5 & 0.03 & 0.000519 & 0.02 & 1.5 & 3022 \\
\hline \multicolumn{9}{|l|}{ Basalt } \\
\hline 75 & 3 & 150.1 & 83.3 & 0.03 & 0.001230 & 0.05 & 0.5 & 2943 \\
\hline \multicolumn{9}{|c|}{ Dolerite/sheeted dikes } \\
\hline 76 & 7 & 211.5 & 74.2 & 0.08 & 0.000503 & 0.02 & 3.9 & 2937 \\
\hline
\end{tabular}


The LOC basalt is exposed on the small island of Storøya, northeast of the main ophiolite body (site 75). In addition, there is a small outcrop of basalt, part of the dolerite/sheeted-dike unit (site 76), on the southeastern shore of Madsøya. The samples are weakly magnetic with NRM values from 0.02 to $0.09 \mathrm{~A} / \mathrm{m}$, and susceptibility values from 0.0005 to 0.0019 (SI). The basalts have a greenschist-facies metamorphic overprint that may have destroyed the magnetite. In thin-section, the only observable oxide is ilmenite with no obvious hematite exsolution.

Site directions are shown on a stereonet in Fig. 3. The majority of directions are steeply dipping with inclinations greater than $50^{\circ}$, and a large range of declinations. The two different harzburgite areas are shown in different colors to illustrate the difference between the two. The western harzburgite is shown in green squares and the eastern in orange squares. The sample- and site-averaged directions are listed in Table 1.
The TMI is the result of the addition of two magnetic vectors, the NRM and the induced magnetization. The induced magnetization $\left(\mathrm{M}_{\mathrm{i}}\right)$ is calculated for the samples by multiplying the volume-normalized magnetic susceptibility $(K)$ of the sample with the magnetic field at the sample's location. On Leka, the magnetic field $(\mathrm{H})$ is $52166 \mathrm{nT}$, or $41.35 \mathrm{~A} / \mathrm{m}$ (IGRF, 2010). Using this, we can determine the contribution of the NRM to the TMI anomaly.

The ratio between the NRM and $M_{i}$ is the Koenigsberger ratio (Q value) given in Equation 1. Over 90\% of the samples have a $\mathrm{Q}$ value greater than 0.5 and more than $66 \%$ are above 1 (Fig. 4). These results suggest that remanence contributes to the magnetic anomaly measured in the aeromagnetic survey and that the NRM directions and intensities are required for modeling the magnetic anomaly. NRM intensities vary both by rock type and by site locations. NRM directions were evaluated for geographic location and rock type; however, a good geographic correlation was not found.

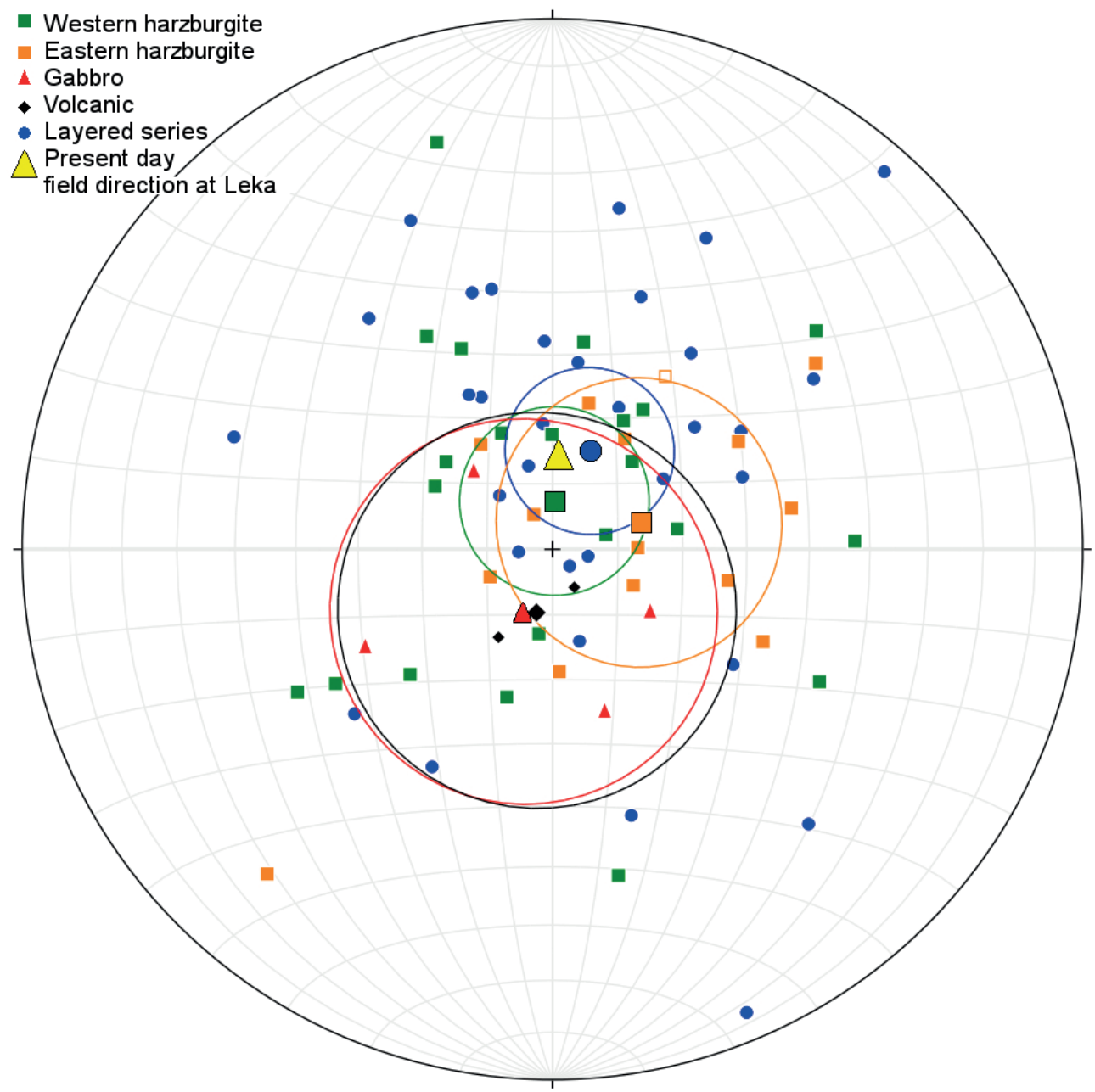

Figure 3. NRM directions for each site are plotted on a stereonet colored by rock unit. The average for each rock unit is represented by a larger symbol of the same rock-unit color with its circle of confidence $\left(a_{95}\right)$. The present field direction (Declination $=3.8^{\circ}$, Inclination $\left.=75.7^{\circ}\right)$ at Leka is shown with a large yellow triangle (IGRF, 2010). Sites with a positive inclination are plotted with closed symbols. Only one site in the eastern harzburgite has a negative inclination and is marked with an open square. 


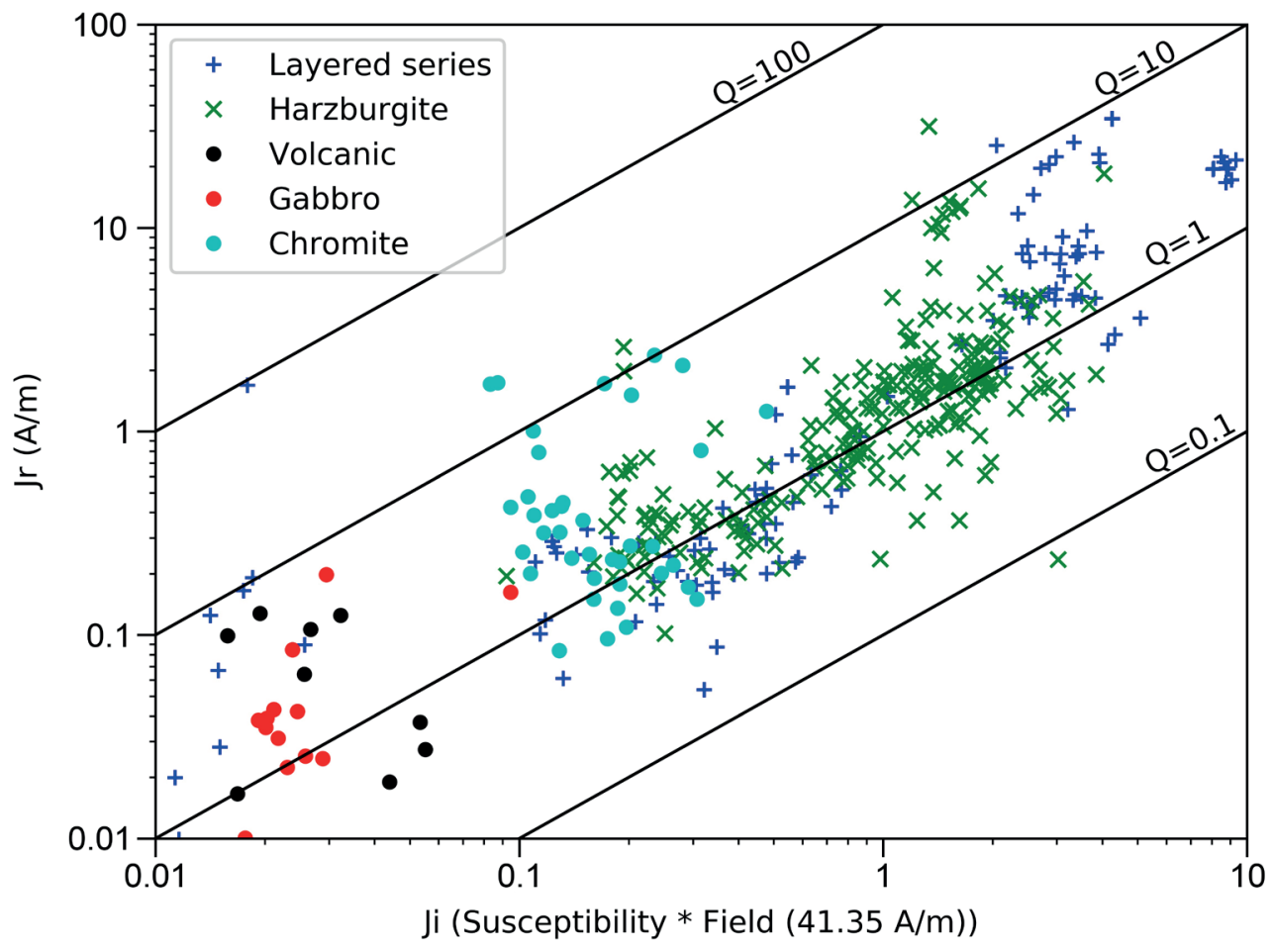

Figure 4. Plot of NRM (Jr) in A/m vs. induced magnetization (Ji) in A/m and lines of constant $Q$ values (Jr/Ji). Samples with NRMs and Ji values less than $0.01 \mathrm{~A} / \mathrm{m}$ are not shown. Layered series samples with densities greater than $3100 \mathrm{~kg} / \mathrm{m}^{3}$ contain more chromite and are shown in light blue circles. Volcanic rocks (black) include samples from basalt and dolerite units.

$$
\mathrm{Q}=\frac{\operatorname{NRM}\left(\frac{\mathrm{A}}{\mathrm{m}}\right)}{\mathrm{K}(\mathrm{SI}){ }^{*} \mathrm{H}\left(\frac{\mathrm{A}}{\mathrm{m}}\right)}
$$

$\mathrm{Q}$ - Koenigsberger ratio, NRM in $\mathrm{A} / \mathrm{m}, \mathrm{K}$ - volume normalized magnetic susceptibility (SI), $\mathrm{H}=41.35 \mathrm{~A} / \mathrm{m}$ is the Earth's magnetic field that has been converted to a volume-dependent magnetization at the samples location (IGRF, 2010).

\section{Density}

The layered series samples have the widest range in density, from 2640 to $3430 \mathrm{~kg} / \mathrm{m}^{3}$ (Fig. 5). The sites with densities greater than $3100 \mathrm{~kg} / \mathrm{m}^{3}$ occur mainly in the northern part of the island where chromite layers occur. One specimen, rich in chromite, has a density of 4035 $\mathrm{kg} / \mathrm{m}^{3}$. Excluding samples that have visible chromite, the range is $2640-3180 \mathrm{~kg} / \mathrm{m}^{3}$ with an average density of $2950 \mathrm{~kg} / \mathrm{m}^{3}$. Sites containing chromite are marked in Table 1 with a ' $c$ '. The highest-density layered series samples without visible chromite appear less altered.

The density of the harzburgite samples ranges from 2690 to $3070 \mathrm{~kg} / \mathrm{m}^{3}$, with an average density of 2790 $\mathrm{kg} / \mathrm{m}^{3}$. One harzburgite locality, site 72 , has a density of $>3000 \mathrm{~kg} / \mathrm{m}^{3}$, the majority of harzburgite samples are $<2900 \mathrm{~kg} / \mathrm{cm}^{3}$.
Densities for the gabbroic samples have an average of $3022 \mathrm{~kg} / \mathrm{m}^{3}$, with a range from 2860 to $3150 \mathrm{~kg} / \mathrm{m}^{3}$ that falls within the range of a typical gabbro. The lowerdensity gabbros are more plagioclase rich and the higherdensity samples contain more pyroxene cumulates. The pillow basalts from Storøya have an average density of $2943 \mathrm{~kg} / \mathrm{m}^{3}$, while the sheeted dike samples from Madsøya have an average density of $2937 \mathrm{~kg} / \mathrm{m}^{3}$.

The ultramafic rocks show varying degrees of serpentinization, indicated by lower densities. Fig. 5A is a plot of NRM intensity vs. density, and Fig. 5B for the magnetic susceptibility vs. density. It is expected that susceptibility and NRM values should increase as the density decreases because the process of serpentinization increases the amount of magnetite. The range in density for these rocks agrees with other samples from serpentinized ultramafic rocks (Toft et al., 1990; Bonnemains et al., 2016).

In Fig. 5A, the NRM values are plotted for each sample vs. their respective densities. The layered series has the largest range of densities and NRM values, with no apparent correlation. All layered series samples with densities $>3100 \mathrm{~kg} / \mathrm{m}^{3}$ contain chromite. In the harzburgites, there is a slightly narrower range in NRM values. However, there is no obvious increase in NRM or susceptibility values with decreasing density as would be expected with increased formation of magnetite due to serpentinization. In the low-density (2700-2800 

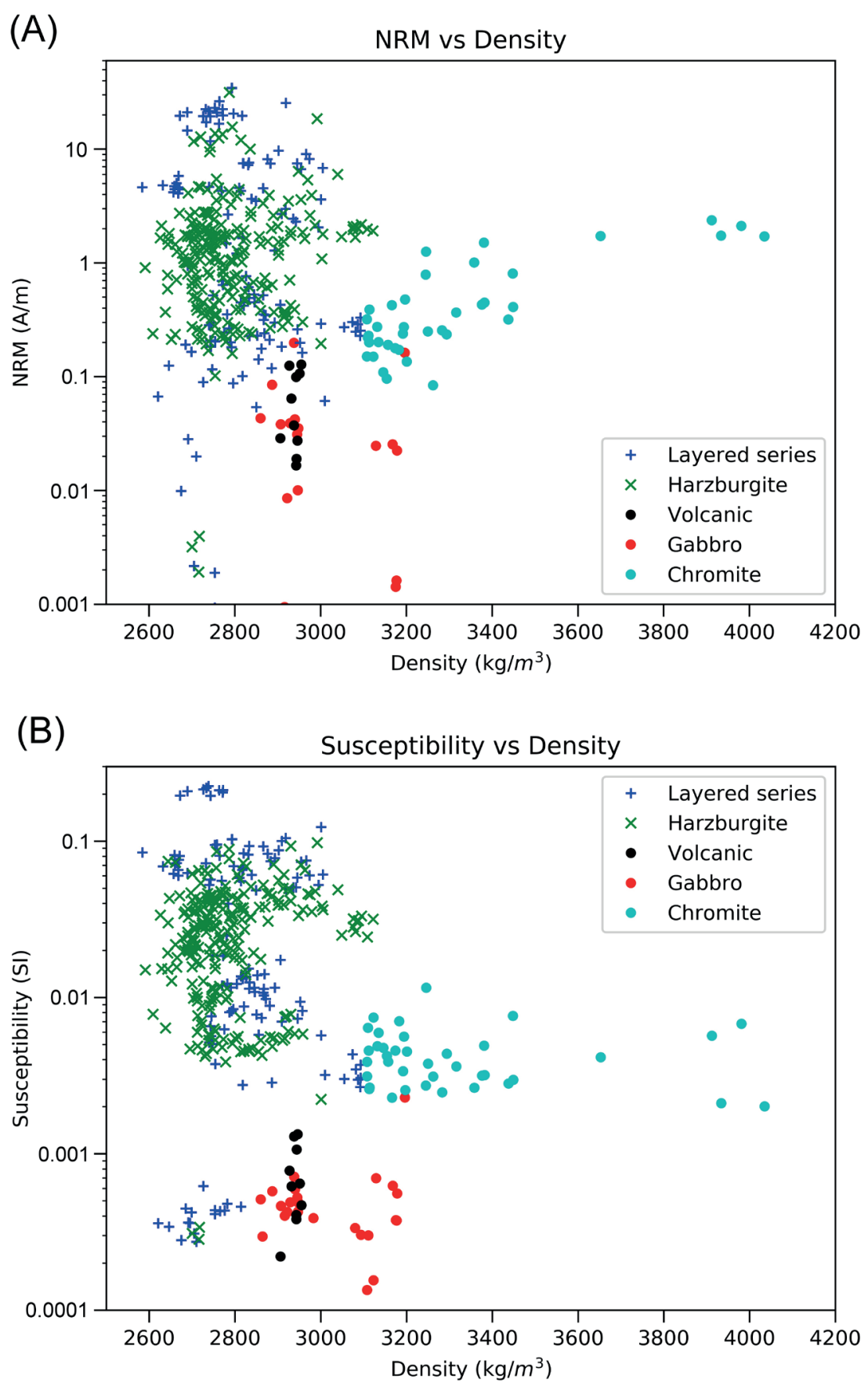

Figure 5. (A) NRM (A/m) vs. density $\left(\mathrm{kg} / \mathrm{m}^{3}\right)$ of 564 specimens. (B) Susceptibility (SI) vs. density $\left(\mathrm{kg} / \mathrm{m}^{3}\right)$. Layered series samples with densities greater than $3100 \mathrm{~kg} / \mathrm{m}^{3}$ contain more chromite and are shown in light blue circles. Volcanic rocks (black) include samples from both basalt and dolerite.

$\mathrm{kg} / \mathrm{m}^{3}$ ) area of the plot (Fig. 5A) the NRM variation is the largest. Magnetite formed by low-temperature serpentinization will result in lower NRM values than a magnetite produced closer to its Curie temperature because a thermal remanent magnetization (TRM) is far more efficient than a chemical remanent magnetization
(CRM). This lack of correlation in NRM values and the density may indicate that a significant amount of magnetite was produced from serpentinization and acquired a CRM at lower temperatures and possibly over an extensive period of time. 


\section{Geophysical data}

\section{Aeromagnetic data and map interpretation}

The aeromagnetic survey used in this study was acquired by NGU (Olesen et al., 2015). Line spacing was $250 \mathrm{~m}$ with tie lines at $2.5 \mathrm{~km}$ intervals. The survey was flown with a direction of $135^{\circ} \mathrm{N}$ and the tie lines were flown at $45^{\circ} \mathrm{N}$. Average sensor elevation was $60 \mathrm{~m}$ above topography with draping over higher elevations on the island, but the draping does not perfectly match the elevation of the island due to steep elevation changes. The drape flying elevation and sensor height over ground are shown in Fig. 6B, C, respectively. Measurements were made with three Geometrics G-822A magnetometers flown in a Cessna Reims F406 and two piper Navajos. The data were provided by NGU as a grid, with a grid cell size of $50 \mathrm{~m}$, corrected for the International Geomagnetic Reference Field (IGRF) model. The resulting grid is shown in Fig. 6G. Filtering was performed using Geosoft Oasis Montaj (Geosoft Inc., 2013). The total magnetic intensity (TMI) ranges from $-770 \mathrm{nT}$ to $2840 \mathrm{nT}$. Over the majority of the LOC, the TMI ranges from $50 \mathrm{nT}$ to 600 nT. A correction for a tilt in the regional magnetic field was not necessary as Leka is expressed as an isolated magnetic anomaly on an almost flat background (see Olesen et al., 2010).

Looking at the magnetic map (Figs. 6G \& 7A), the most dominant magnetic anomaly low $(-770 \mathrm{nT})$ is visible off the north shore of the island along the inferred contact between the harzburgite and the country rock. The most striking magnetic high is a nearly linear magnetic anomaly (up to $2840 \mathrm{nT}$ ) traversing the LOC along the tectonic contact between the gabbro and layered series units and along the contact between gabbro and the harzburgite northeast of the gabbro/layered series contact. Layered series samples collected near this contact (site 3) have very high NRM intensities (range from 16.7 to $22.4 \mathrm{~A} / \mathrm{m}$ ) and an average susceptibility of 0.2096 (SI). Other layered series samples collected near the magnetic high, though farther from the contact (sites $7-9,14,26$, and 31), have site-averaged NRM values between 0.30 and $4.38 \mathrm{~A} / \mathrm{m}$ and a susceptibility range from 0.0063 to 0.0997 (SI).

As noted earlier, all of the gabbroic rock samples were low in both remanence and susceptibility. This is reflected in the overall magnetic response of the main gabbroic body which is just above the background (Fig. $6 \mathrm{G})$. In contrast, the gabbro samples near the fault were all weakly magnetic with an average NRM intensity of $0.01 \mathrm{~mA} / \mathrm{m}$ and a susceptibility of 0.0003 (SI). The 2400 nT magnetic anomaly high near the fault area requires an additional source of magnetization, likely residing underneath the gabbro that would produce the magnetic anomaly observed. We interpret the origin of this large positive anomaly to be due to the formation of magnetite by serpentinization of ultramafic rocks below and along the fault contact, rather than originating in the gabbroic rocks, as shown below. This large magnetic contrast suggests that the tectonic contact between the gabbro and the ultramafic bodies is magnetic and has a low angle of dip to the east. The dip has been determined by modeling, continuously adjusting the angle and thickness to obtain the best fit to the measured magnetic data, as discussed below.

\section{Gravity data and map interpretation}

During the course of regional gravity surveys in 19871994, NGU collected two hundred gravity measurements on and around the island of Leka using a Lacoste \& Romberg gravimeter. Positions and elevations of the gravity station have an elevation precision between 1 and $3 \mathrm{~m}$, which corresponds to 0.3 to $1 \mathrm{mGal}$ (Titus et al., 2002). An additional 13 data points were collected by the Norwegian Mapping Authorities and merged with the dataset of NGU (Olesen et al., 2010). The gravity stations are shown in Fig. 6D. Most of the gravity measurements were acquired along roads, along a few traverses across the island, and on the surrounding islands. These data were gridded using the Minimum Curvature algorithm in Geosoft's Oasis Montaj with a grid cell size of $50 \mathrm{~m}$.

The LOC is located in an area of crustal thinning towards the northwest, in a transition zone between continent and continental shelf, as documented on the crustal thickness map by Ebbing \& Olesen (2010). The consequence of this transition is that the regional gravity field increases to the northwest. In order to focus on the LOC without full crustal modeling on a regional scale, the gravity data were corrected for the regional background trend. Using an appropriate regional background provides an important constraint for the modeling of the subsurface geometry of the LOC, as discussed below. For this purpose, the gravity compilation of NGU (Ebbing \& Olesen, 2010; 2 x $2 \mathrm{~km}$ grid cell size) has been used. In an area of 50 x 50 $\mathrm{km}$, centered on the LOC, a trend surface of polynomial degree of 1 has been fitted to the anomalies, excluding the anomalies of the LOC. The trend surface, which has a slope of $0.49 \mathrm{mGal} / \mathrm{km}$ and a dip direction towards eastsoutheast, was subtracted from the gravity data of the LOC yielding the residual free-air gravity anomalies (Fig. $6 \mathrm{~F})$. This residual is consistent with the residual gravity anomaly map of NGU (Gellein, 2006). The Bouguer anomaly (Olesen et al., 2010; correction density $2670 \mathrm{~kg} /$ $\mathrm{m}^{3}$ ) has been added in Fig. 6D in order to gain a rough idea of the subsurface of the LOC, though a higher correction density would give a more precise result. The free-air gravity was used for modeling.

Apart from a few measurements on the northeastern tip of the island, the residual free-air gravity measurements show values from 10 to $66 \mathrm{mGals}$. The free-air gravity 
Topography + bathymetry

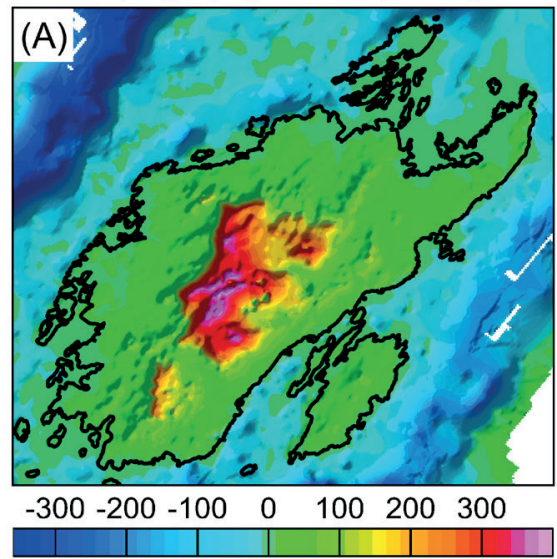

(m)

Bouguer gravity anomaly

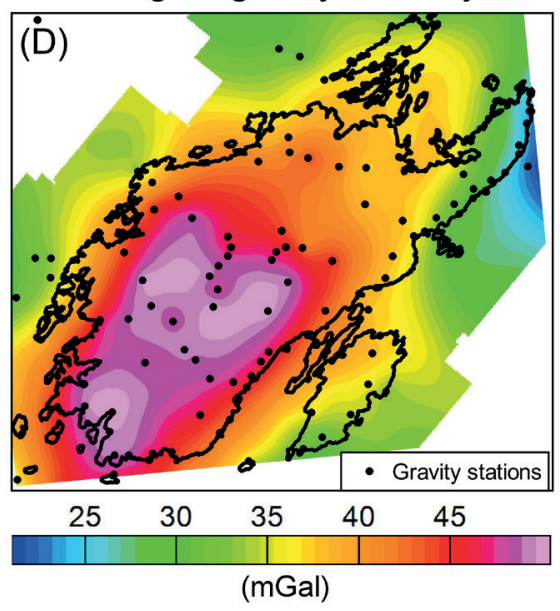

Aeromagnetic anomaly

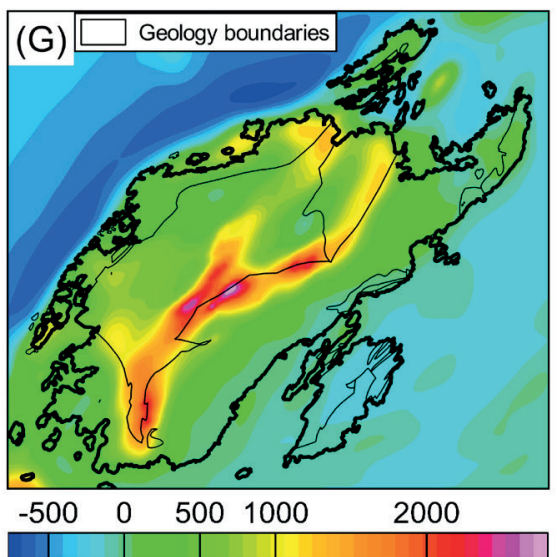

(nT)
Flight height (m.a.s.I.)

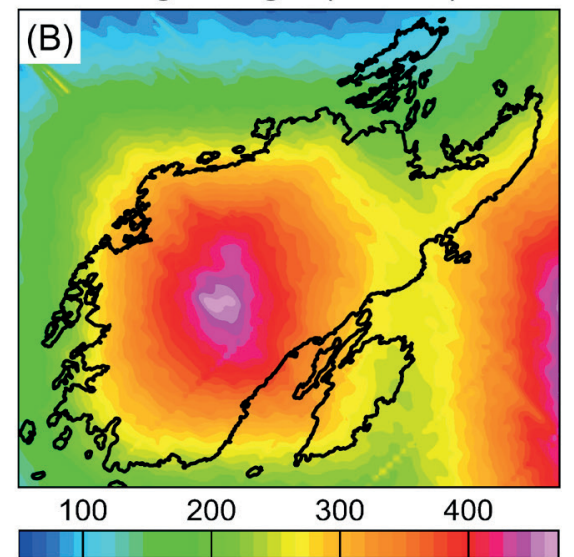

(m)

Free-air gravity anomaly

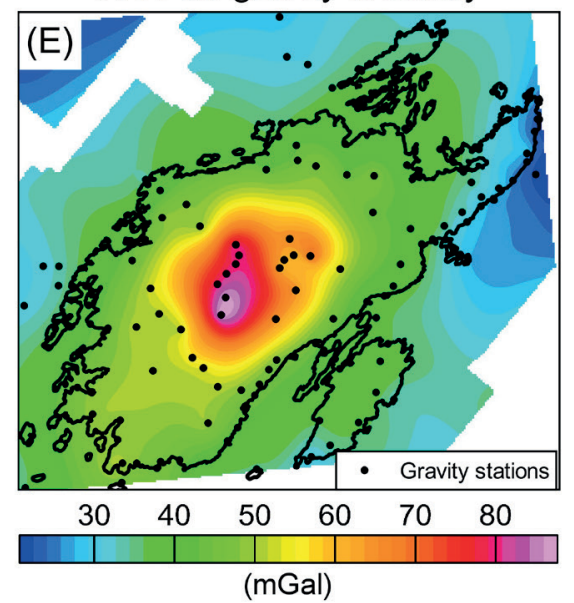

Aeromagnetic anomaly upward continued to $500 \mathrm{~m}$

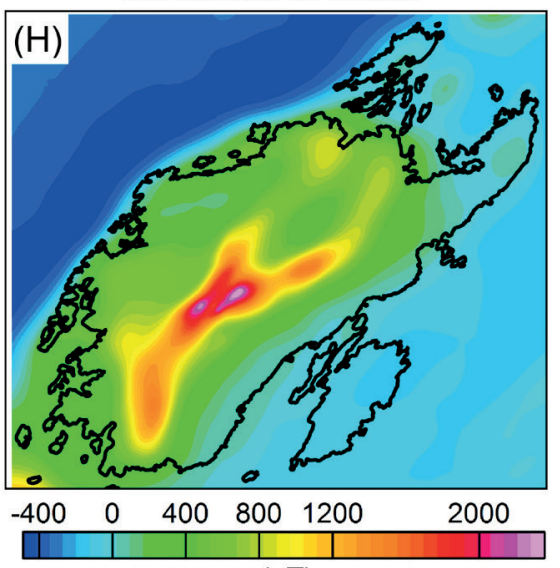

(nT)
(Flight height) - (topography)

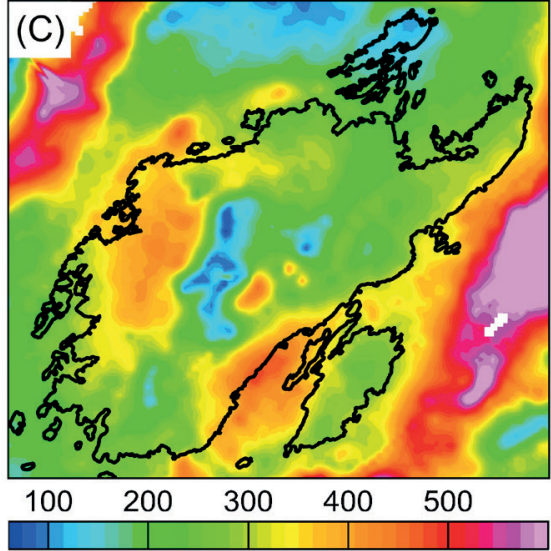

(m)

Residual free-air gravity anomaly

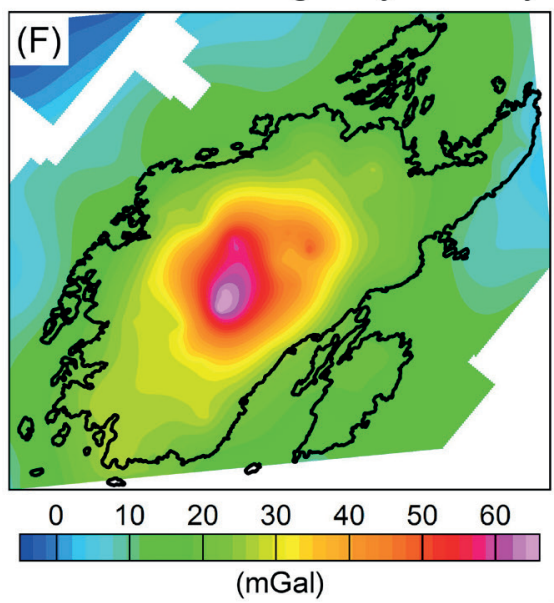

Magnetic vertical gradient

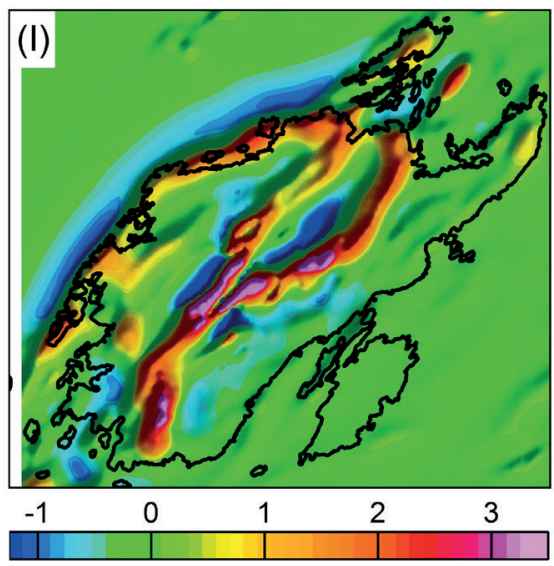

(nT/m)

Figure 6. (A) Topography and bathymetry of the study area. (B) Flight height of the aeromagnetic survey in meters above sea level (m.a.s.l). (C) Difference between the flight height (B) and the terrain elevation (A). (D) Bouguer gravity anomaly data from Olesen et al. (2010) with gravity stations (black dots). Stations that are not on the island were measured on skerries that are not shown on the map. The Bouguer gravity map shows highs in the center and in the southwest, indicating a deeper extent of the LOC. (E) Free-air gravity anomaly from Olesen et al. (2010) with the gravity high centered around the highest point of the island. (F) Residual free-air gravity anomaly map, calculated by removing the regional gravity trend from the free-air gravity map (E). (G) Aeromagnetic map created from data from Olesen et al. (2015) showing the magnetic high following the contact between the gabbro and the ultramafic rocks. The geological contacts (black lines) are from Pedersen et al. (2011). (H) Upward continuation to $500 \mathrm{~m}$ of the draped aeromagnetic anomaly map $(G)$. (I) Vertical gradient of the magnetic anomaly map highlighting fault contacts, and calculated as the difference between the aeromagnetic map $(G)$ and its upward-continuation $(H)$ divided by the difference between $500 \mathrm{~m}$ and the flight height $(B)$. 


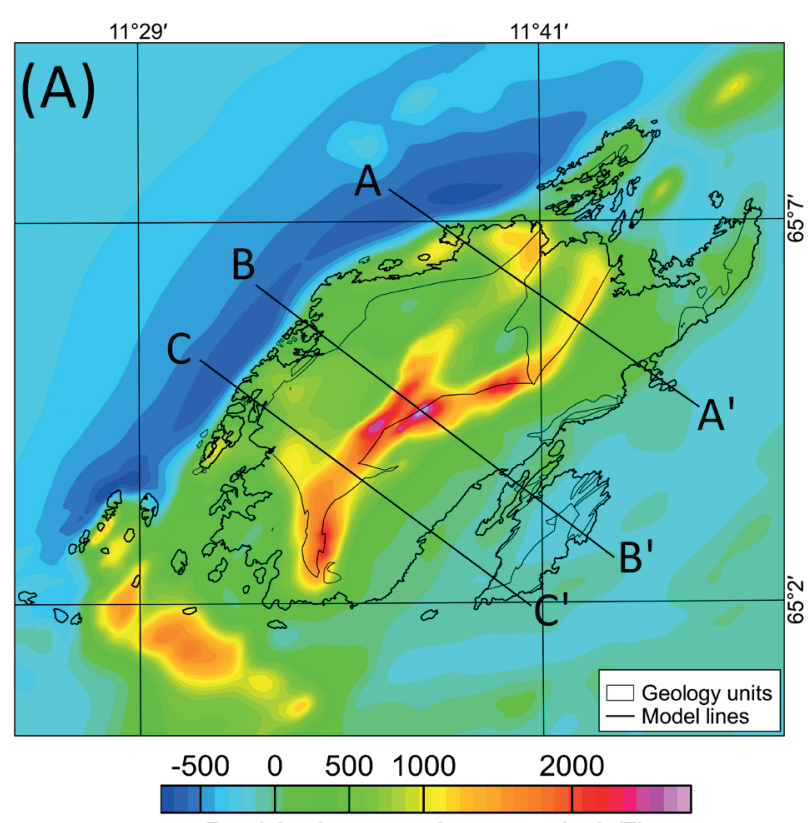

Residual magnetic anomaly (nT)

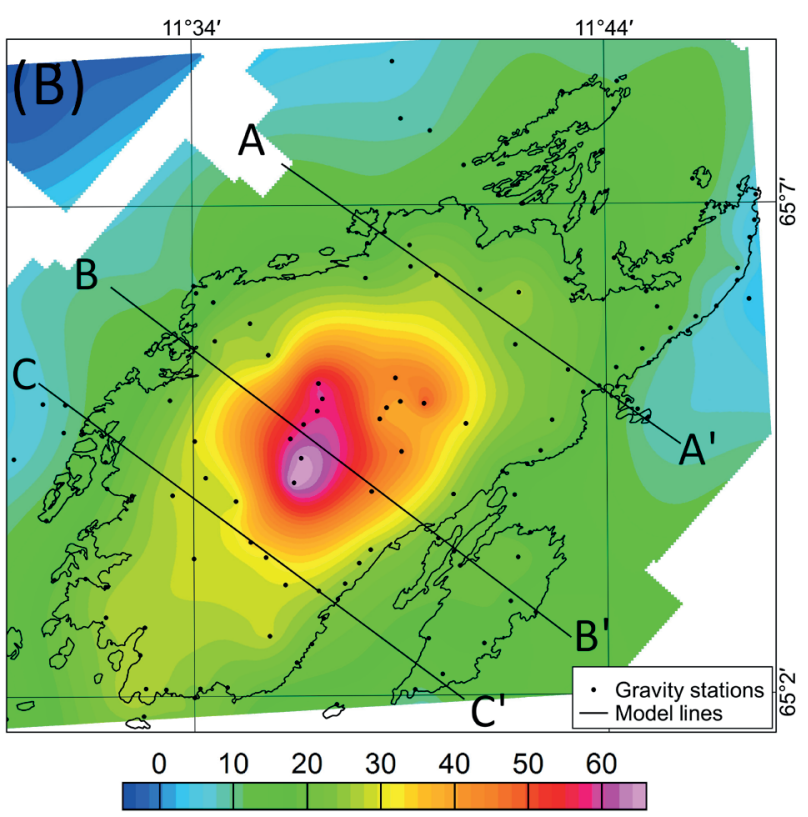

Residual free-air gravity anomaly (mGal)

Figure 7. (A) The aeromagnetic map with magnetic anomaly values ranges from -770 to $2840 \mathrm{nT}$ and the locations of three cross-sections are shown here from northeast to southwest $\left(A-A^{\prime}, B-B^{\prime}, C-C^{\prime}\right)$. (B) Residual free-air gravity anomaly map (Fig. $6 F$ ) includes the locations for gravity measurements (black points) and modelled profiles. The free-air gravity anomaly values for the island of Leka vary from 10 to $67 \mathrm{mGal}$. Gravity measurement sites that are located off the island of Leka were measured by NGU on small islands or skerries surrounding Leka.

anomalies define a distinct high correlating with the topographic highs in the center of the island, whereas the Bouguer-corrected anomalies document an additional high in the southern part of the island, indicating an increasing depth of the complex towards the south.

\section{Modeling}

\section{Profile selection}

The locations of cross-sections used for modeling are shown in Fig. 7A, B. These were chosen to show the overall structure of the LOC. The trend of the sections is approximately perpendicular to the dominant magnetic anomaly trends. Because there were too few gravity measurements on the island of Storøya, and in between the island of Leka and Storøya, the basalts in this area were not included in the models, even though the aeromagnetic map covers Storøya and the water between them.

The northern- $\left(\mathrm{A}-\mathrm{A}^{\prime}\right)$ and southern-section $\left(\mathrm{C}-\mathrm{C}^{\prime}\right)$ lines were chosen due to proximity to the road that circumnavigates the island, where most of the gravity measurements were made, and to avoid areas where interpolation between widely spaced measurement points is needed.
The middle line (section B-B') passes through the dominant magnetic anomaly high and near the freeair gravity high on Leka. However, there is a gap in the spacing of gravity stations on the northwestern side of this section, leading to large areas of interpolation. The applied minimum curvature gridding resulted in a gradual decrease of the interpolated gravity anomalies between the stations at the top of the cliff and the one at the base of the cliff. However, because the elevation rapidly drops at this location, this would result in a rapid decrease in gravity. Therefore, the interpolated gravity values are assumed to be overestimated and the interpolated values removed, whereas the modelled gravity points have been kept. The extent and orientation of this section includes the small island of Madsøya to the southeast, where the basalts are located. Madsøya is also crossed by section $\mathrm{C}-\mathrm{C}$. This middle line (B-B') approximately corresponds to one of the previous lines from Sindre \& Pedersen (1990) and Titus et al. (2002).

\section{Modeling method}

GMSYS2D software by GEOSOFT Oasis Montaj was used for 2.5D modeling of the gravity and magnetic anomalies. The 2.5D models assume that the structures shown in the depth section strike perpendicular to the section plane. Their length in map plane is limited in both directions and reflects the overall extension of the LOC, estimated to $14 \mathrm{~km}$. For the deepest parts of sections $\mathrm{B}-\mathrm{B}$ ' and $\mathrm{C}-\mathrm{C}$ ', the lateral extent of the structures 
was lower in order to reflect the deep 3D geometry of the LOC. Outside the structure's extent country-rock properties are used, approximating a 3D modeling effect.

The program extracted station points along the profiles from the gravity and magnetic anomaly grids, at flight altitude for magnetic stations and at ground elevation for the gravity stations. At each of these stations, the respective measured (or interpolated) value is compared to the calculated values. When establishing possible models along parallel sections, the calculated data must be given an offset, such that the anomalies taper out to the same background level; therefore, a point is included in every section that represents background level outside of the anomaly. The calculated gravity response was required to taper to zero, according to our regional-trend field correction, described earlier. This procedure ensures that the parallel sections refer to the same background level.

The gravity and magnetic models are constrained by the densities and magnetic properties from the 540 samples reported here, and from values by Sindre \& Pedersen (1990) for the country rock. Depth, density and magnetic properties were varied within the observed ranges of our data to find the best fit of modelled and observed gravity and magnetic anomalies.

Initially, the NRM values used in the models were constrained by data from these geographic locations, i.e., the western blocks of harzburgite had the general direction of the western samples, and eastern blocks were given slightly different directions related to the eastern harzburgite samples. This starting direction was changed to obtain a better fit within the range of directions that were measured. Given the NRM variability within the sample dataset (Table 1) of 564 samples (Fig. 3) there was a large range that could be used for developing the models. The declination had little effect because most of the directions have steep inclinations, and thus the declination was set to obtain a best fit in the model.

Due to the lack of information on densities, susceptibilities and NRM directions at depth, the measured surface values were tested in the model parts at greater depths and gradually adjusted to fit the overall gravity and magnetic anomalies. At greater depth, the model is composed of large homogeneous blocks, whereas the model blocks near the surface are smaller and reflect the variations in properties that were measured.

\section{Modeling tests}

The modeling started by matching the gravity data with a model constrained by the rock units' densities and mapped geology. This model was subsequently modified in order to match the magnetic data and measured magnetic properties.
We established a starting model of the LOC with a simple assumption of vertical continuation of the surface rocks to an unknown depth using the measured densities and magnetic properties. Excluding the local chromite-rich samples, the average density for the exposed ultramafic rocks, which are all serpentinized, is $2810 \mathrm{~kg} / \mathrm{m}^{3}$, and for the gabbros is $3022 \mathrm{~kg} / \mathrm{m}^{3}\left(2950 \mathrm{~kg} / \mathrm{m}^{3}\right.$ for the region surrounding section $\left.\mathrm{B}-\mathrm{B}^{\prime}\right)$. Therefore, using one overall density for the LOC is not feasible, and the LOC is split into different parts based on lithology. The resulting model that fits the gravity data is shown in Fig. 8. The first impression of the shape of the LOC from gravity is a rounded body with a bowl-shaped bottom. This simple model, which fits the gravity data, leads to a large misfit and offset of the magnetic anomalies, most pronounced at the highest mountains in the center of the LOC.

A first modification applied to the model (Fig. 8) removes the misfit in the longer wavelengths by introducing a vertical change for the ultramafic rocks, where the density increases and magnetic susceptibility decreases. Overall, this combination of parameters could reflect a less serpentinized body at depth. The model shown in Fig. 9 was derived by varying the densities and susceptibilities to obtain the best fit in agreement with our reported parameters of serpentinized ultramafic rocks. From exploratory drillcores that were taken from Leka it is known that there are areas of significant serpentinization extending to at least $100 \mathrm{~m}$ below the surface (Olerud, 1990). Surface samples have densities that vary from highly serpentinized $\left(2700 \mathrm{~kg} / \mathrm{m}^{3}\right)$ to weakly serpentinized $\left(3100 \mathrm{~kg} / \mathrm{m}^{3}\right)$. Therefore, we conclude that the degree of serpentinization varies in the LOC, and there must be areas of less serpentinized ultramafic rocks, with higher density, at deeper levels. In all the models presented in Figs. 10, 11, 12 \& 13, the near-surface ultramafic blocks are serpentinized and the properties reflect the measured values. Figs. $8 \& 9$ suggest that the best fit for the density of the gabbroic part of the LOC is $3000 \mathrm{~kg} / \mathrm{m}^{3}$.

Finally, the model requires further adjustment near the top of the highest mountain, at the location of the largest NE-SW-trending fault. The poor fit of the observed and calculated magnetic data could only be removed by changing the dip angle of the fault to a lower angle at greater depth (Fig. 10). This model still contains disparities in the short wavelength of the magnetic anomalies at the top of the model, indicating a more complex distribution of magnetic properties in this area, addressed below. The new model in Fig. 10 sets the maximum depth for the base of the LOC to approximately $2.8 \mathrm{~km}$ below the surface, with a rounded bowl-like shape. This model provides the basis for more detailed models, presented and discussed below. 

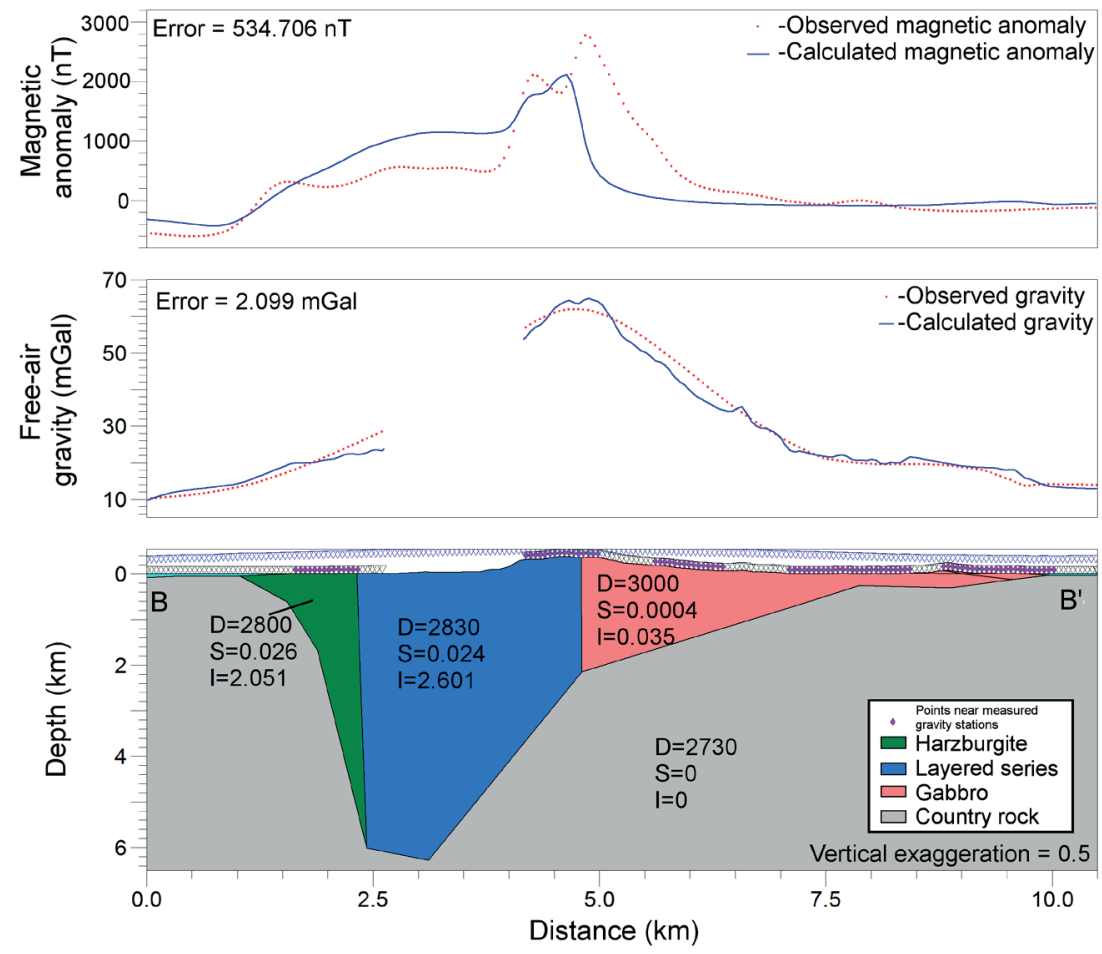

Figure 8. Sensitivity test along section B-B' that uses surface properties and vertical contacts. This model was made to obtain the best fit for the gravity model by changing only the depth of the LOC's base. However, this model does not result in a good match between the calculated and the observed magnetic anomaly. The blue triangles mark the location and flying height of the aeromagnetic survey, while the black triangles mark the level of the gravity survey (topography plus instrument height). The pink triangles represent stations where the gravity point on profile was within $300 \mathrm{~m}$ distance to a gravity measurement, and measurements which were more than $500 \mathrm{~m}$ away from the profile were not included in order to avoid aliased interpolation of the data. These are indicated as gaps along the profile. D-density $\left(\mathrm{kg} / \mathrm{m}^{3}\right), S-$ magnetic susceptibility (SI), I- magnetic intensity $(\mathrm{A} / \mathrm{m})$.
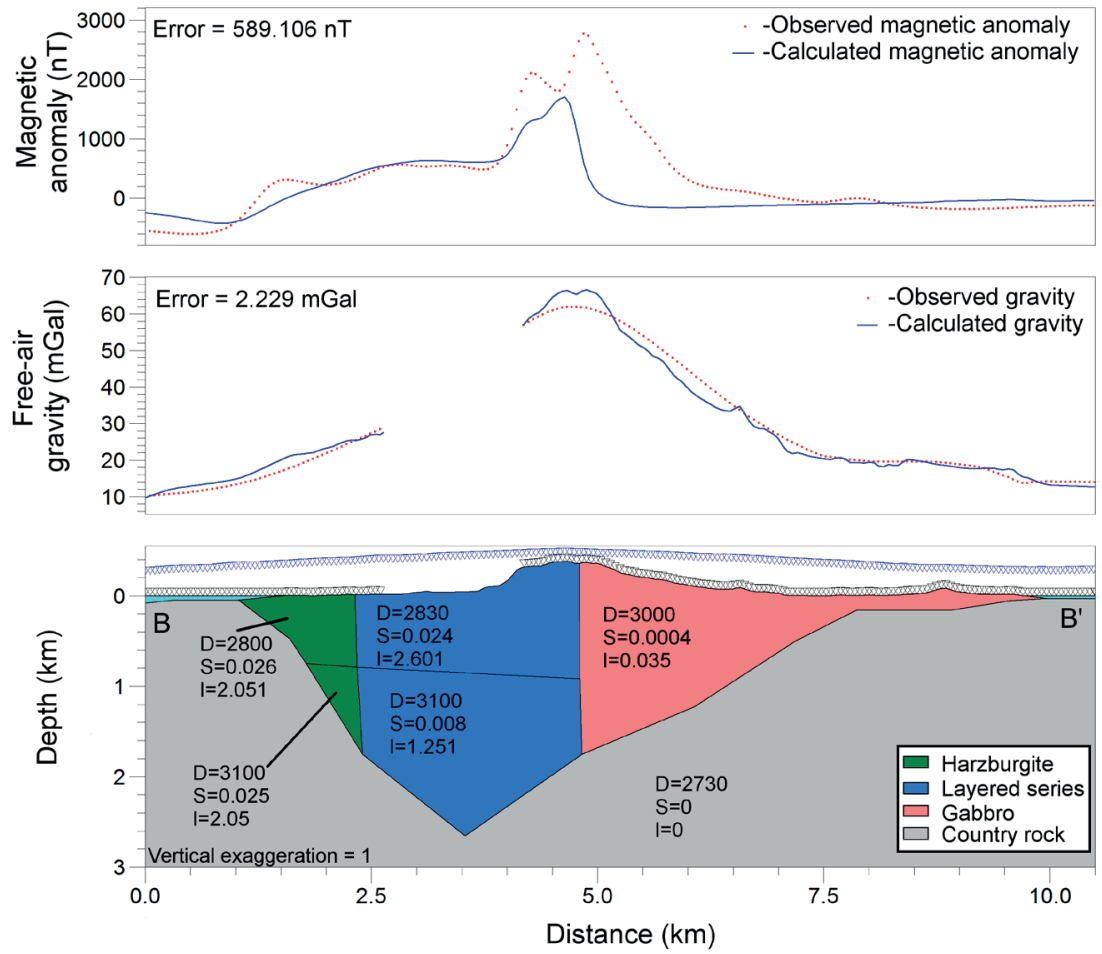

Figure 9. Sensitivity test along section $B-B^{\prime}$ that uses vertical contacts, and surface properties that increase in density and decrease in the magnetization with depth. This increase in density causes the base of the LOC to be shallower than the model in Fig. 8. This denser and less magnetic layer could be explained by a lower degree of serpentinization. The match between the calculated and the observed magnetic anomaly is improved to the left of the magnetic high compared to Fig. 8. However, there is still a large error. Considering the slope of the observed magnetic anomaly over the gabbro, increasing the magnetization of the lithological units would not improve the model. D - density $\left(\mathrm{kg} / \mathrm{m}^{3}\right), S-m a g n e t i c$ susceptibility (SI), I - magnetic intensity $(\mathrm{A} / \mathrm{m})$. See caption of Fig. 8 for gravity measurement points. 

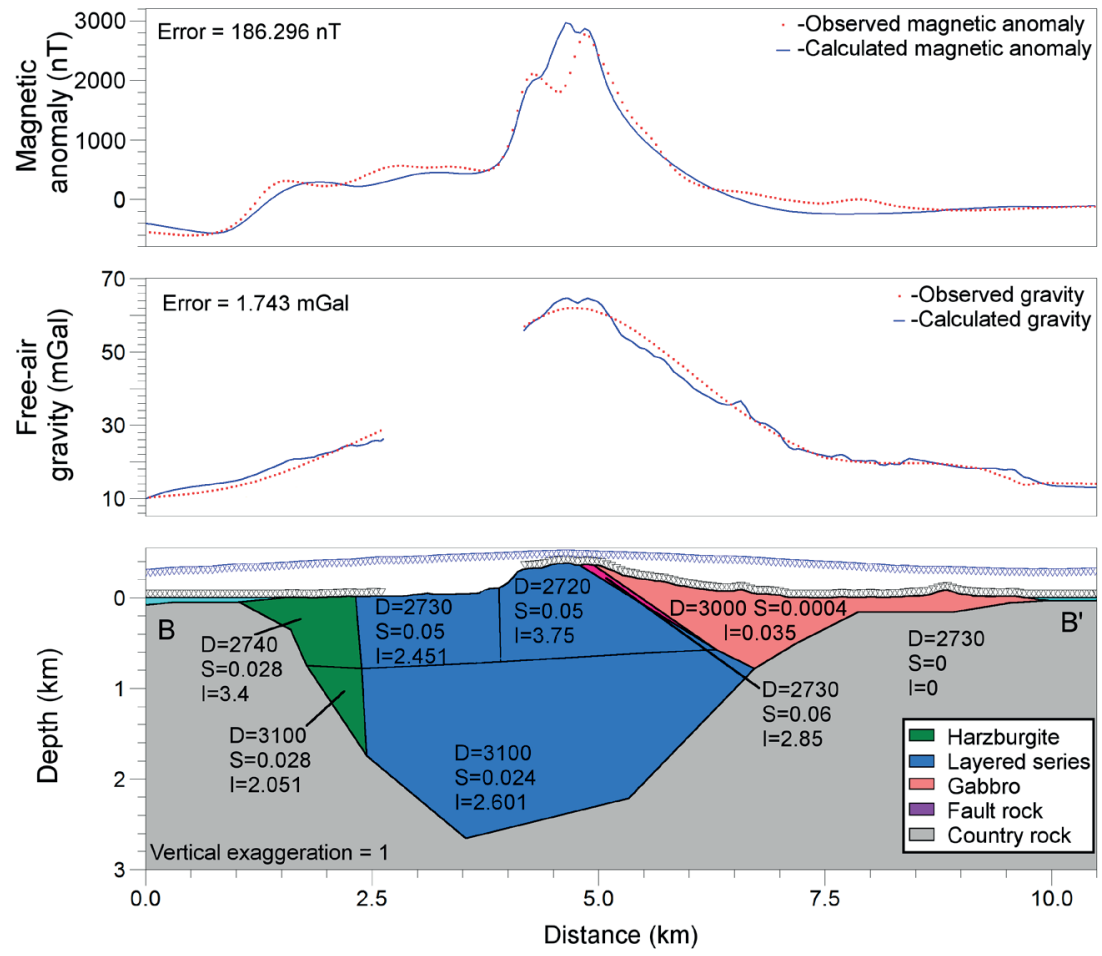

Figure 10. This sensitivity test, along section B-B', uses vertical contacts to the left of the magnetic high, and an eastward-dipping contact between the layered series and the gabbro. This contact is modeled by a 'layer' of fault rocks with slightly higher magnetization than the average of the layered series. This allows for a better fit of the amplitude and slope of the magnetic anomalies. The magnetic high over the gabbro is the result of a magnetic layer beneath it rather than the gabbro itself which has weak magnetic properties. $D$ - density $\left(\mathrm{kg} / \mathrm{m}^{3}\right), S-m a g n e t i c$ susceptibility (SI), I - magnetic intensity $(\mathrm{A} / \mathrm{m})$. See caption of Fig. 8 for gravity measurement points and units.

\section{Description of model sections}

\section{Northern section A-A'}

The northern section A-A' crosses the only area in the LOC where the harzburgite is well exposed both to the east and west of the layered series (Fig. 1). Maaløe (2005) reported that the eastern contact of harzburgite and layered series that represents the petrologic paleo-Moho dips towards the northwest, forming one branch of the synform. Farther to the east, a mapped fault separates the gabbro from the harzburgite (Fig. 11). The fault gouge of this plane does not appear to be very thick. Properties of the rock surrounding the fault were used on the sections adjacent to the fault and the petrophysical parameters were adjusted to compensate for increased serpentinization (lower density and higher magnetic susceptibility), along with its thickness. Because there was a large difference in magnetic properties between the harzburgite, altered fault rock and the weakly magnetic gabbro, it was possible to determine the dip of the fault contact by varying the dip until it fits the TMI anomaly field. The fault is shallow with a $45^{\circ}$ dip towards southwest as shown in Fig. 11.
The higher density $\left(2980 \mathrm{~kg} / \mathrm{m}^{3}\right)$ used for this layered series block is due to the presence of chromite layers in this region, even though the layered series is partly serpentinized.

\section{Middle section B-B'}

This model section B-B' (Fig. 12) and also section C-C' contain a unit not present in the previous section, which on the geologic map (Fig. 1) is listed as dolerite/sheeted dikes. The dikes are weakly magnetic (Table 1).

The location of section B-B' coincides with the model section by Sindre \& Pedersen (1990). It crosses the anomaly maxima in both the free-air gravity and the magnetic-anomaly datasets. The terrain forms a ridge that runs perpendicular to the model line. With a large gap in gravity measurements from the base of the cliff to the top of the ridge, gridding produces an interpolation of low-angle slope, rather than one that mimics the terrain as described above. This ridge also has an effect on the resulting magnetic anomalies because the survey was not perfectly draped over the high terrain and resulted in a steep decay of the magnetic signal where 

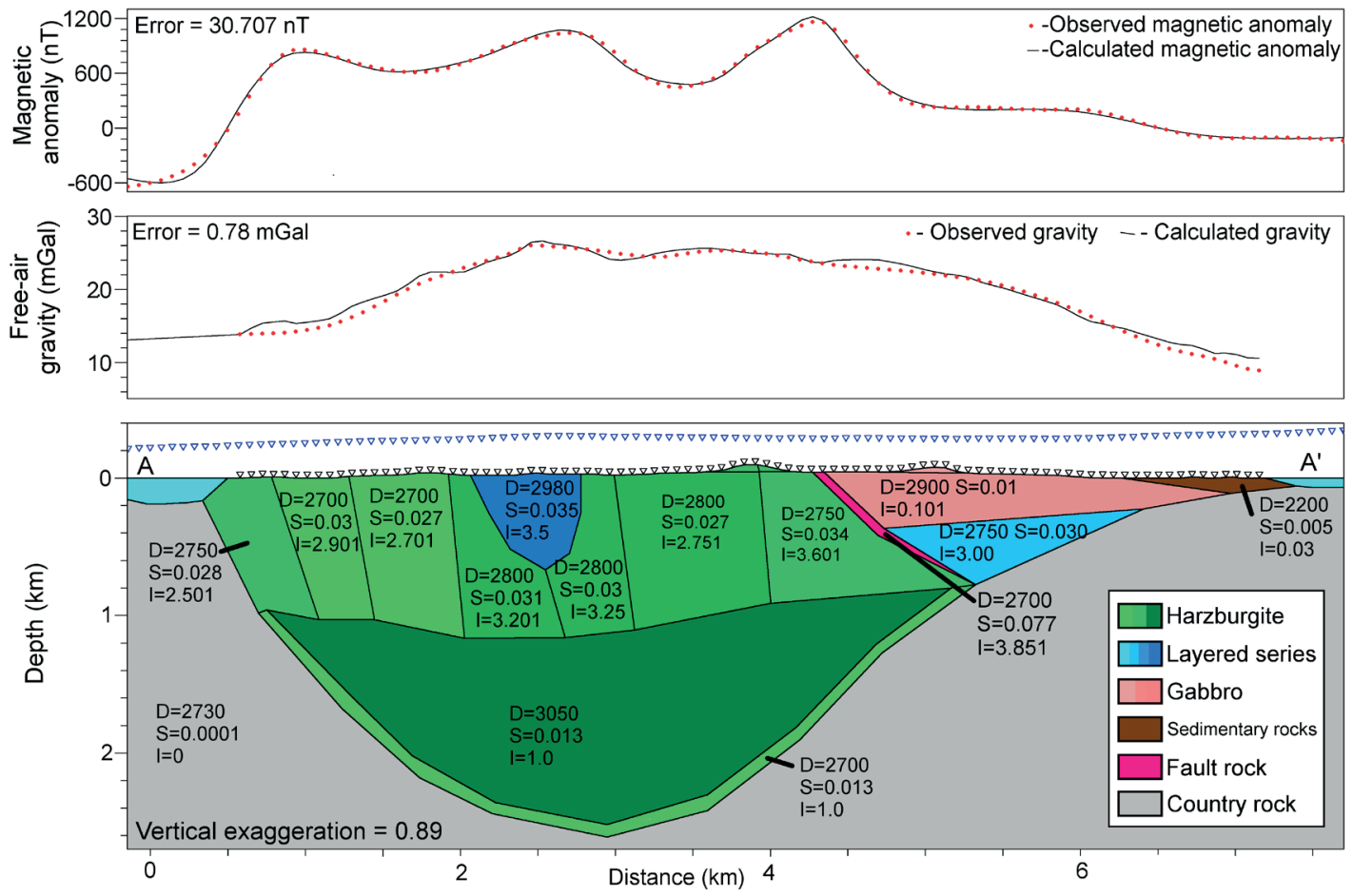

Figure 11. A 2.5D gravity and magnetic model along section A-A'. The thin, less dense layer surrounding the base of the LOC represents the contact between the LOC and the country rock, where an increase in serpentinization similar to that seen in the fault is likely. These blocks extend laterally $4000 \mathrm{~m}$ to the northeast (into the page) and $11,000 \mathrm{~m}$ to the southwest (out of the page). D - density $\left(\mathrm{kg} / \mathrm{m}^{3}\right), S-m a g n e t i c$ susceptibility (SI), I - magnetic intensity (A/m). See caption of Fig. 8 for details on gravity measurement points.
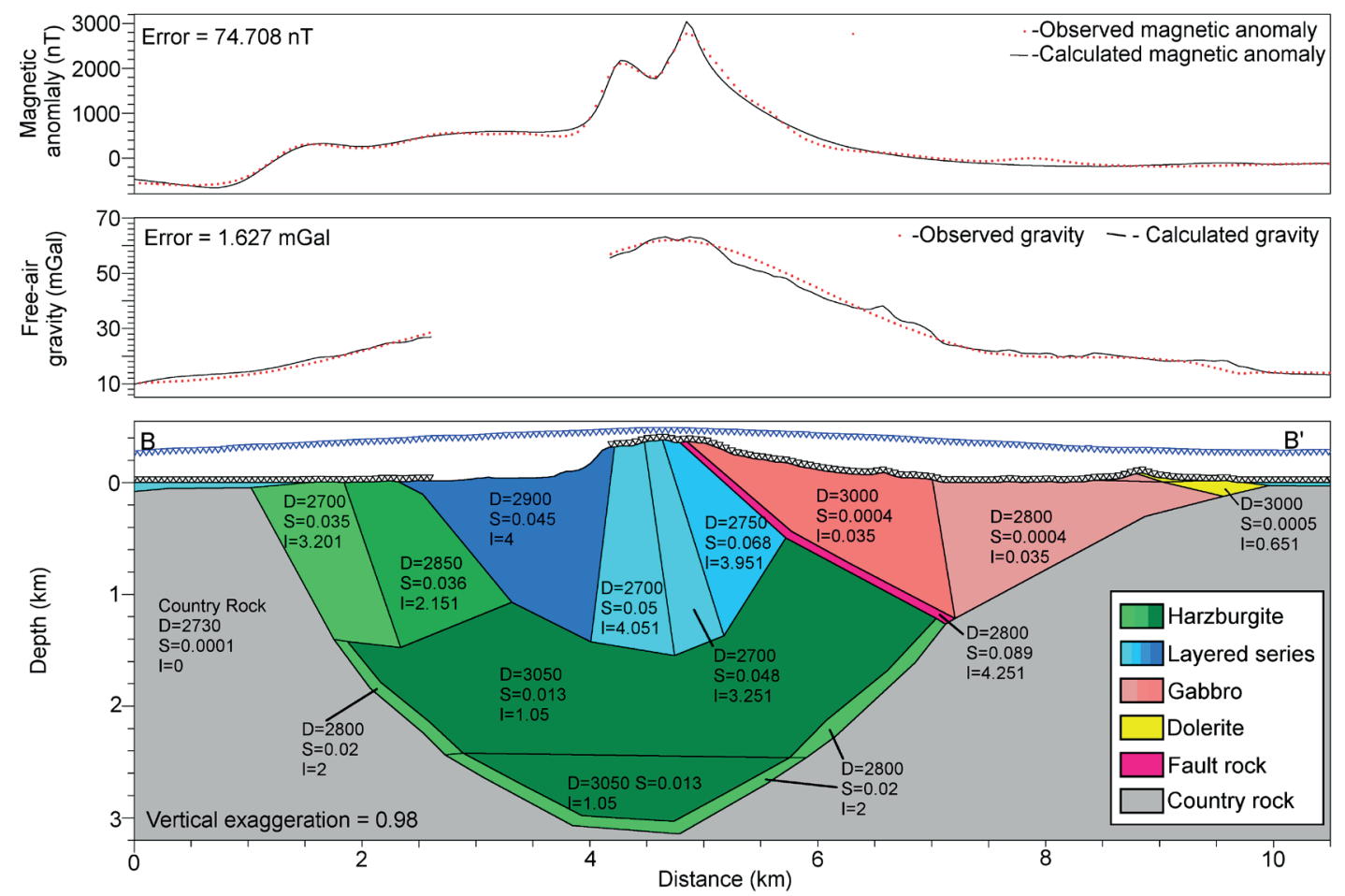

Figure 12. A 2.5D gravity and magnetic model along section B-B'. The thin, less dense layer surrounding the base of LOC represents the contact between the LOC and the country rock as in Fig. 11. The lowermost block extends laterally $2000 \mathrm{~m}$ to the northeast (into the page) and 6000 $m$ to the southwest (out of the page). The other blocks in this model extend laterally $6000 \mathrm{~m}$ to the northeast (into the page) and $8000 \mathrm{~m}$ to the southwest (out of the page). D - density $\left(\mathrm{kg} / \mathrm{m}^{3}\right), \mathrm{S}$ - magnetic susceptibility (SI), I - magnetic intensity (A/m). See caption of Fig. 8 for gravity measurement points. 
the terrain drops off steeply. Furthermore, a very strong magnetic anomaly is measured over the top of the ridge, where the magnetic sensor is much nearer to the terrain than elsewhere (Fig. 6C, G).

Model section B-B' crosses the dominant aeromagnetic anomaly on the island, which coincides with the fault contact between layered series and gabbro. Where the fault corresponds to the aeromagnetic anomaly, higher susceptibility and NRM values of the rock units are necessary to model the observed magnetic response, in agreement with values of samples collected in the area. The orientation of the fault is modified to match the slope of the observed magnetic and gravity data.

\section{Southern section $\mathrm{C}-\mathrm{C}^{\prime}$}

The location of model section C-C' (Fig. 13) was chosen to correspond with the road where gravity measurements were acquired to avoid unconstrained areas of interpolation in the gravity grid. This model resulted in the largest depth of the three sections (3800 $\mathrm{m})$, suggesting that the LOC is deformed in a southwestward-plunging synform. Model section C-C' includes the largest exposure of both the layered series and the gabbro of the three model sections, and includes near-surface blocks that are serpentinized.

\section{Composite and 3D interpolation model}

Combining the sections shown in Figs. 11, 12 \& 13, a composite model is shown in Fig. 14. Using the displayed geometries and the surface geology map from Fig. 1, a 3D geologic model of the LOC was created using Leapfrog GEO (Fig. 15). By digitizing the lines between the contacts along the models lines the program builds a mesh, and calculates a volume for each rock unit. With this $3 \mathrm{D}$ model we estimate the volume of the entire LOC as well as the individual units (Table 2). The estimated volume for the

Table 2. Volume estimates of major rock units based on the Leapfrog Geo 3D model of Leka as seen in Fig. 15.

\begin{tabular}{lc}
\hline Rock Unit & Estimated volume $\left(\mathrm{km}^{3}\right)$ \\
\hline Harzburgite (green) & 137.81 \\
Layered series (blue) & 33.04 \\
Gabbro (red) & 32.60 \\
\hline Total & 203.45 \\
\hline
\end{tabular}
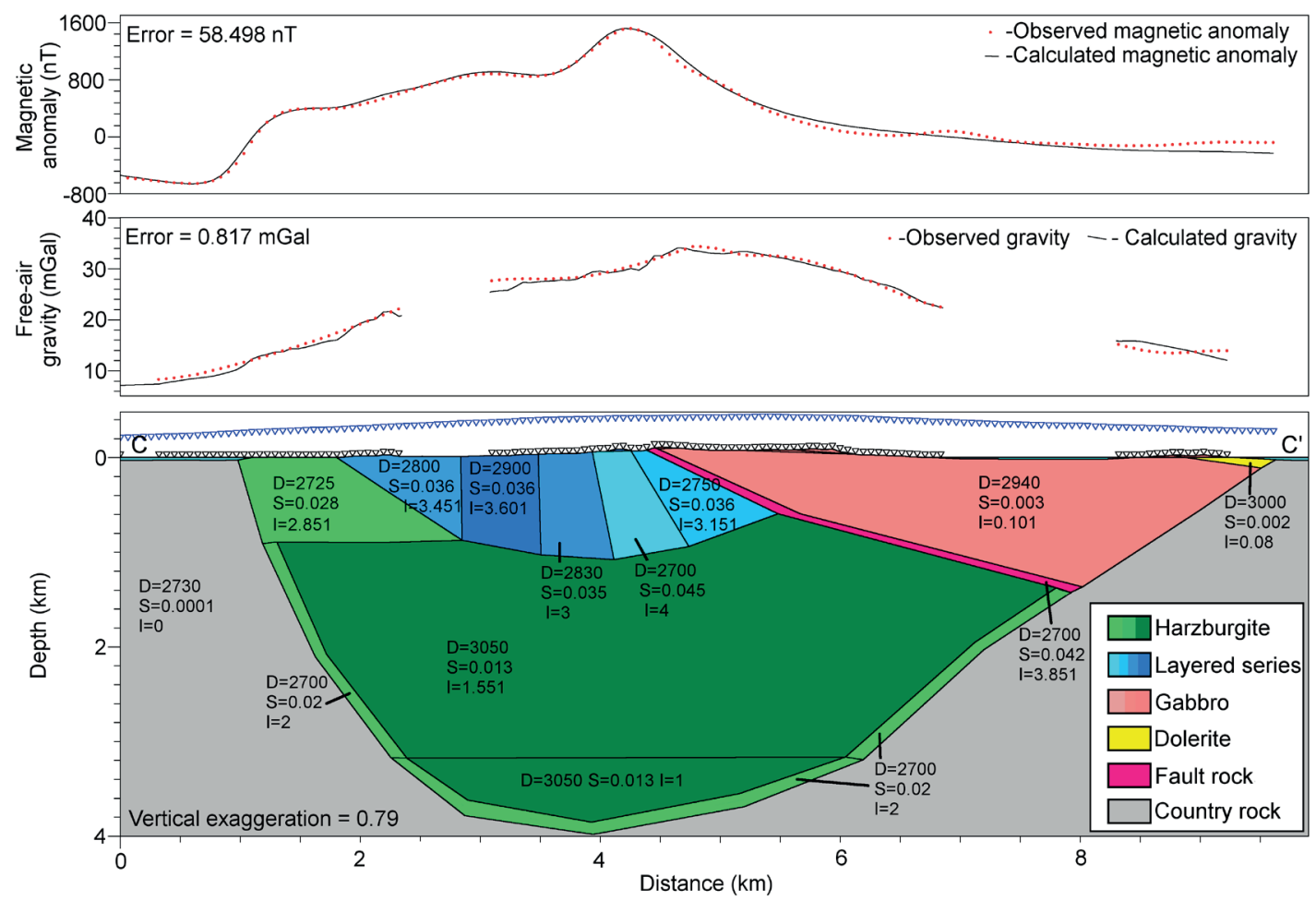

Figure 13. A 2.5D gravity and magnetic model along section C-C'. The contact between the LOC and the country rock is modeled by a thin, less dense layer surrounding the base of LOC, as in Fig. 11. The lateral extent of the lowermost block is $1000 \mathrm{~m}$ to the northeast (into the page) and $4000 \mathrm{~m}$ to the southwest (out of the page). The other blocks in this model extend laterally $8000 \mathrm{~m}$ to the northeast (into the page) and $4000 \mathrm{~m}$ to the southwest (out of the page). D - density ( $\mathrm{kg} / \mathrm{m} 3), \mathrm{S}$ - magnetic susceptibility (SI), I - magnetic intensity (A/m). See caption of Fig. 8 for gravity measurement points. 
entire LOC based on this model is $203 \mathrm{~km}^{3}$. The resulting $3 \mathrm{D}$ model is displayed in Fig. 15. Here, the LOC is shown as a synform with a sequence of harzburgite, layered series and gabbro/basalts in its western part. The eastern part of the LOC is dominated by a large listric fault (pink layer in Fig. 15E), indicating a major displacement of the gabbroic unit (red) along the shallow-dipping fault.

\section{Comparison with earlier models}

Previous models of the LOC were presented by Sindre \& Pedersen (1990, p. 13, fig. 8) and Titus et al. (2002, p.
109, fig. 5b). These models were based solely on gravity modeling. Both studies modeled the Bouguer gravity anomaly and concluded that the LOC has steep vertical sides with a relatively flat base. Their models were simpler in density structure than our models, and less constrained due to fewer density measurements. One difference from our results is the greater maximum depth of the complex. Sindre \& Pedersen (1990) suggested a maximum depth of near $6 \mathrm{~km}$ by modeling with vertical blocks of different densities. The difference to our model depth from that of Sindre \& Pedersen (1990) can be attributed to: 1) a missing correction for the regional background, 2) different lateral extension of the bodies at
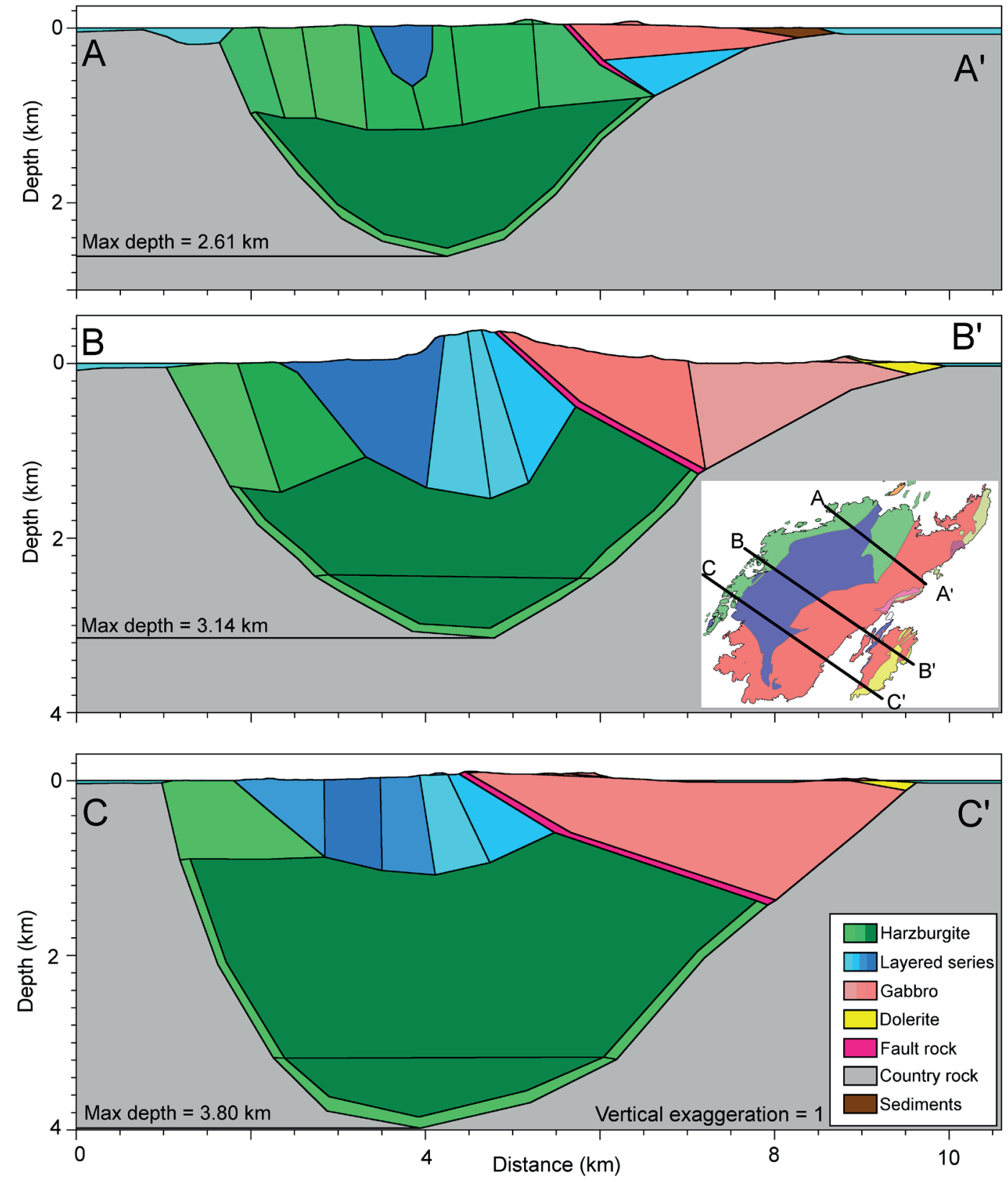

Figure 14. Structure and lithology for each of the three modeled cross-sections are shown using the same scale with their respective maximum depths. Variations in density are designated with shading (lighter is less dense, darker is denser). Detailed properties used in the models are shown in Figs. 11, $12 \& 13$. 


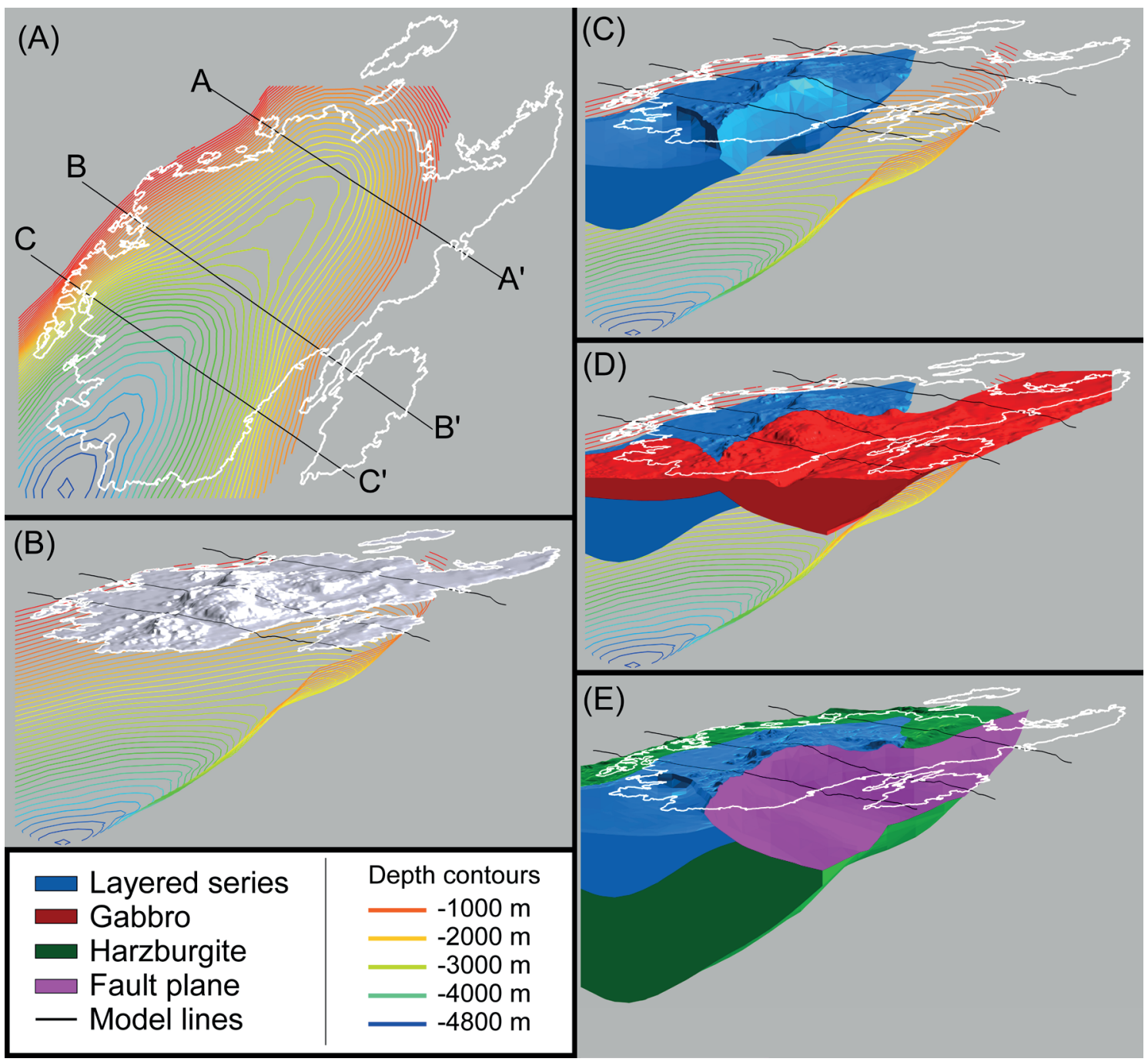

Figure 15. A 3D depth model developed in Leapfrog GEO with modeled section localities and coastline is shown in different views. (A) Contours of the base of the harzburgite are shown with modeled section localities and coastline (white). (B) Contours of the base of the harzburgite including digital elevation model of the LOC. (C) Contours of the base of the harzburgite including 3D depth model of the layered series (blue). (D) Contours of the base of the harzburgite including $3 D$ depth models of the layered series (blue) and the gabbro (red). (E) $3 D$ depth models of the layered series (blue), harzburgite (green), and fault plane (pink).

the greatest depth, and 3) unknown choice of Bouguercorrection density. With the standard correction density of $2670 \mathrm{~kg} / \mathrm{m}^{3}$, the masses of the LOC above sea level would be underestimated, and their positive gravity effect attributed to the rocks below sea level.

Titus et al. (2002) used an even simpler model. They used the same Bouguer gravity data as Sindre \& Pedersen (1990), applied an unspecified regional-trend correction and modelled the entire complex with one density contrast $\left(400 \mathrm{~kg} / \mathrm{m}^{3}\right)$. They performed a 3D gravity inversion and achieved a maximum depth of $7 \mathrm{~km}$. Their resulting complex is much larger in lateral extent than our complex and extends towards the southeast far into onshore land areas, where no ophiolites are exposed, and farther towards the northwest where we know today, from the new magnetic data, that the complex is confined. It is unknown whether they corrected for the density difference between Bouguer-correction density $(2670 \mathrm{~kg} /$ $\mathrm{m}^{3}$ ) and the higher densities of the masses of the LOC above sea level, which, uncorrected, would result in a mass excess attributed to the rocks at greater depth and subsequently a larger maximum depth of the LOC.

\section{Discussion}

This is the first model of the Leka Ophiolite Complex that incorporates both magnetic and gravity data integrated with earlier published structural information. The gravity data are the primary tool for defining the maximum depth of the complex, whereas the magnetic data best constrain the contacts, fault orientation, and the changes in physical properties due to serpentinization. 
A cursory glance at the aeromagnetic and geology maps of the LOC shows a magnetic high that corresponds to the contacts between the gabbro and the layered series, as well as the contact between the gabbro and the harzburgite on the eastern side of the island. This major contact is mapped as faults on older geologic maps (Furnes et al., 1988).

The magnetic data were upward continued to an altitude of $500 \mathrm{~m}$ and subsequently the vertical gradient was calculated (Figs. 6I \& 16). This results in a high-pass filter effect (Fig. 16) and delineates and highlights the main faulted contact of the down-dropped gabbro onto the layered series and mantle rocks. This is shown by a continuous positive magnetic anomaly that is attributed to the increase in serpentinization along the fault zone. This is likely due to the increase in the amount of peridotite (mostly dunite and harzburgite) altered to serpentinite, which resulted in an increase in magnetite content. Minor faults can also be correlated with positive magnetic highs in this map. The variation of the magnetic anomaly intensity along the ridge, with the extremely high values at the highest elevations, is related to the low flying height above the top of the ridge, as discussed earlier.

Our interpretation is supported by the density measurements of 493 layered series and harzburgite surface samples with an average density of $2811 \mathrm{~kg} /$ $\mathrm{m}^{3}$, clearly indicating that the near surface area is serpentinized. This is also reported by previous authors (Olerud, 1990; Iyer et al., 2008; Plümper et al., 2012; Daae et al., 2013). At depth in the layered series and harzburgite sections, the amount of serpentinization varies, and overall there must be areas at depth with higher densities than those measured at the surface. This inference is based on the interpretation of the most prominent free-air gravity high on Leka, where a higher density is necessary at depth to produce the positive gravity anomaly in all the models presented here. We tested whether it is possible that the entire LOC is more serpentinized than modeled here, but it is difficult to have the body be less dense at depth and still fit the gravity data as illustrated in Fig. 8. Most likely, there are areas at depth in the LOC where more local serpentinization occurred due to enhanced fluid availability, though these volumes at depth are too small to be accurately modelled. The model here uses a realistic geological shape for the complex and shows the possibility that the LOC is shallower than in previously presented models (Sindre \& Pedersen, 1990; Titus et al., 2002).

Further work may include interpretation of the magnetic high that continues to the southwest of Leka (Fig. 7A). Considering samples from the small islands around Leka, which are mainly gneisses and are all weakly magnetic, as reported in the NGU petrophysical database, we consider the possibility that this magnetic high is the result of the LOC extending beyond the boundaries of the island to the southwest, though any exposure is under water.

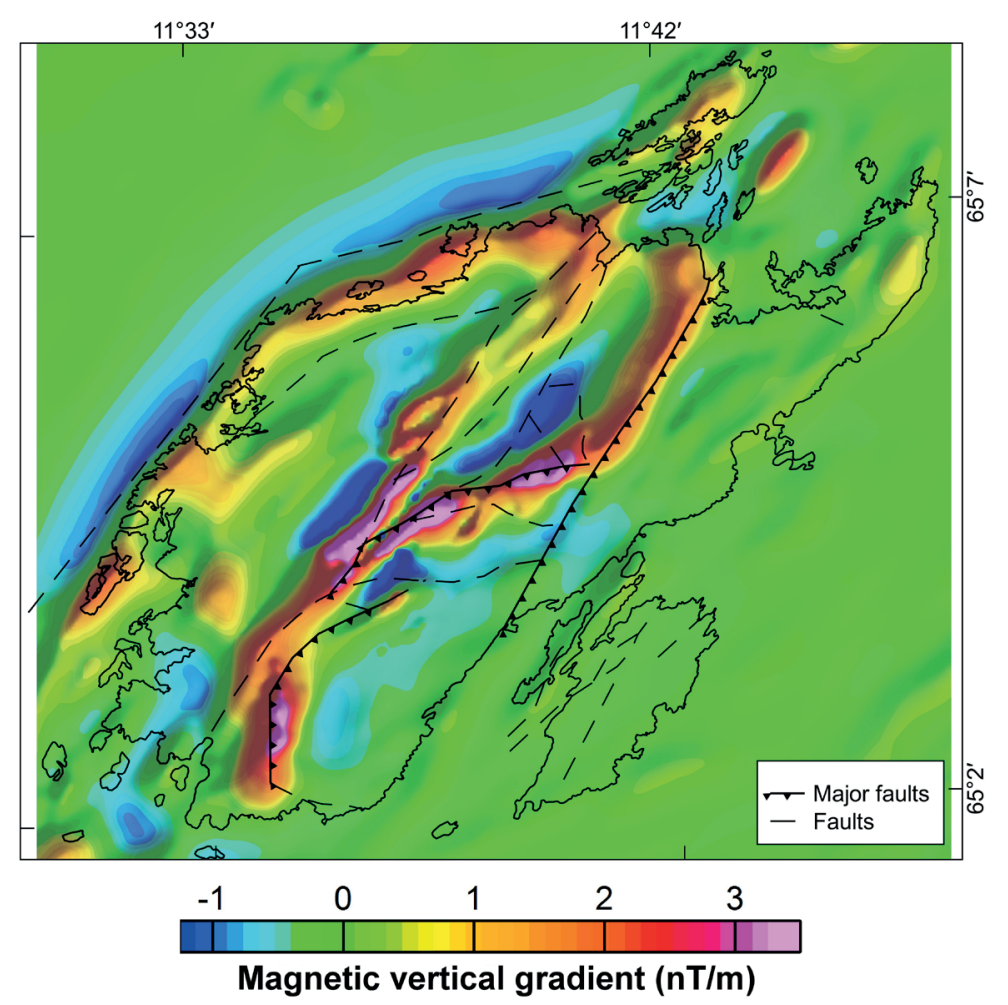

Figure 16. Vertical gradient of the magnetic anomalies overlain with major mapped faults reported by Furnes et al. (1988) and Titus et al. (2002). 
Finally, further work may also provide a more extensive interpretation of the NRM with respect to the paleomagnetic history of the LOC. A paleomagnetic fold test could be performed to confirm whether the magnetization was acquired before or after folding. Petrological modeling by Bjerga et al. (2015) indicates that parts of the LOC were subjected to elevated temperatures during the Scandian orogeny, which could have resulted in a partial to complete overprint of the NRM.

\section{Conclusions}

This study sheds new insights on the structure of the Leka Ophiolite Complex and is a major improvement on the previous models put forth by Sindre \& Pedersen (1990) and by Titus et al. (2002), which were based only on gravity data. Our model uses both gravity and high-resolution aeromagnetic data, in conjunction with petrophysical properties, and petrological observations to constrain the parameters of the model. We suggest that the LOC is folded in a synformal structure, with a maximum depth of approximately $3800 \mathrm{~m}$, shallower than the previously reported depth of $7 \mathrm{~km}$. The major low-angle normal fault, which dropped the gabbro down onto the mantle rock, has a dip between $30^{\circ}$ and $50^{\circ}$. The estimated volume of the LOC from the model in Fig. 15 is approximately $203 \mathrm{~km}^{3}$. Potential-field modeling indicates that the LOC is variably serpentinized, with significant alteration of the layered series and harzburgite at the surface. The LOC is partially serpentinized at depth; however, to fit all the available data it is clear that the surface samples are more serpentinized than some deeper areas of the LOC, which must be of higher density to fit the potential field data. The 564 NRM directions presented here indicate that the LOC had a complicated thermal history and serpentinization likely occurred over a long period of time. The models, and petrophysical data presented here, significantly contribute to our understanding of the present-day structure of LOC.

Acknowledgements. The Research Council of Norway grant 222666 to $\mathrm{S}$. McEnroe supported this research. NGU provided gravity and aeromagnetic data. The fieldwork could not have been done without the many field assistants, Geertje ter Maat, Nathan Church, Zeudia Pastore, Andrea Biedermann, Hedda Jensen, and Alexandra McEnroe. Jostein Hiller was a guide and boat driver to the smaller islands around Leka, and Rolf Pedersen graciously provided his expertise on Leka geology and field guidance. Steinar Ellefmo provided feedback on using Leapfrog GEO to develop the 3D model. Discussions and editing expertise by Peter Robinson, and Laurie Brown, and earlier reviews by Bill Morris, and an anonymous reviewer are appreciated.

\section{References}

Albrektsen, B., Furnes, H. \& Pedersen, R. 1991: Formation of dunites in mantle tectonites, Leka Ophiolite Complex, Norway. Journal of Geodynamics 13, 205-220. https://doi.org/10.1016/0264-3707(91)90039-H.

Bjerga, A., Konopásek, J. \& Pedersen, R.B. 2015: Talc-carbonate alteration of ultramafic rocks within the Leka Ophiolite Complex, Central Norway. Lithos 227, 21-36. https://doi.org/10.1016/j.lithos.2015.03.016.

Blakely, R.J., Brocher, T.M. \& Wells, R.E. 2005: Subduction-zone magnetic anomalies and implications for hydrated forearc mantle. Geology 33, 445-448. https://doi.org/10.1130/G21447.1.

Bonnemains, D., Carlut, J., Escartín, J., Mével, C., Andreani, M. \& Debret, B. 2016: Magnetic signatures of serpentinization at ophiolite complexes. Geochemistry, Geophysics, Geosystems 17, 2969-2986. https://doi.org/10.1002/2016GC006321.

Brongniart, A. 1821: Sur le gisement ou position relative des ophiolites, euphotides, jaspes, etc. dans quelques parties des Apennins. Annales des Mines 6, Paris, 177-238.

Bucher-Nurminen, K. 1991: Mantle fragments in the Scandinavian caledonides. Tectonophysics 190, 173-192. https://doi.org/10.1016/0040-1951(91)90429-V.

Clark, D.A. 1999: Magnetic petrology of igneous intrusions: implications for exploration and magnetic interpretation. Exploration Geophysics 30, 5-26. https://doi.org/10.1071/EG999005.

Daae, F., Økland, I., Dahle, H., Jørgensen, S., Thorseth, I. \& Pedersen, R. 2013: Microbial life associated with low冈temperature alteration of ultramafic rocks in the Leka ophiolite complex. Geobiology 11, 318-339. https://doi.org/10.1111/gbi.12035.

Dilek, Y. \& Furnes, H. 2011: Ophiolite genesis and global tectonics: Geochemical and tectonic fingerprinting of ancient oceanic lithosphere. Geological Society of America Bulletin 123, 387-411. https://doi.org/10.1130/B30446.1.

Dilek, Y. \& Furnes, H. 2014: Ophiolites and Their Origins. Elements 10, 93-100. https://doi.org/10.2113/gselements.10.2.93.

Dunning, G. \& Pedersen, R. 1988: U/Pb ages of ophiolites and arcrelated plutons of the Norwegian Caledonides: implications for the development of Iapetus. Contributions to Mineralogy and Petrology 98, 13-23. https://doi.org/10.1007/BF00371904.

Ebbing, J. \& Olesen, O. 2010: New compilation of top basement and basement thickness for the Norwegian continental shelf reveals the segmentation of the passive margin system. In Vining, B.A. \& Pickering, S.C. (eds.): Geological Society of London, Petroleum Geology Conference series 7, Geological Society of London, pp. 885897. https://doi.org/10.1144/0070885.

Flinn, D. 2000: The architecture of the Shetland Ophiolite. Scottish Journal of Geology 36, 123-135. https://doi.org/10.1144/sjg36020123.

Furnes, H., Pedersen, R. \& Stillman, C. 1988: The Leka Opholite Complex, central Norwegian Caledonides: field characteristics and geotectonic significance. Journal of the Geological Society 145, 401412. https://doi.org/10.1144/gsigs.145.3.0401.

Furnes, H., Pedersen, R., Hertogen, J. \& Albrektsen, B. 1992: Magma development of the Leka ophiolite complex, central Norwegian Caledonides. Lithos 27, 259-277. https://doi.org/10.1016/0024-4937(91)90003-4.

Gellein, J. 2006: Residual gravity map, Vega, scale 1:250,000, Geological Survey of Norway.

Geosoft Inc. 2013: Apply DC Shift in GM-SYS Profile Modeling. Technical Documentation. Tutorial. Geosoft Inc., Canada. http://www.geosoft.com/support/downloads/technicaldocumentation (accessed 26.05.17). 
Hollocher, K., Robinson, P., Seaman, K. \& Walsh, E. 2016: Ordovicianearly Silurian intrusive rocks in the northwest part of the Upper Allochthon, mid-Norway: Plutons of an Iapetan volcanic arc complex. American Journal of Science 316, 925-980.

https://doi.org/10.2475/10.2016.01.

(IGRF) International Association of Geomagnetism and Aeronomy, 2010: International Geomagnetic Reference Field - 11th Generation. National Geophysical Data Center, NOAA.

https://doi.org/10.7289/V58050JN [June 2016].

Iyer, K., Austrheim, H., John, T. \& Jamtveit, B. 2008: Serpentinization of the oceanic lithosphere and some geochemical consequences: constraints from the Leka Ophiolite Complex, Norway. Chemical Geology 249, 66-90. https://doi.org/10.1016/j.chemgeo.2007.12.005.

Maaløe, S. 2005: The dunite bodies, websterite and orthopyroxenite dikes of the Leka ophiolite complex, Norway. Mineralogy and Petrology 85, 163-204. https://doi.org/10.1007/s00710-005-0085-5.

Manghnani, M.H. \& Coleman, R.G. 1981: Gravity profiles across the Samail ophiolite, Oman. Journal of Geophysical Research: Solid Earth 86, 2509-2525. https://doi.org/10.1029/JB086iB04p02509.

McArthur, K.L., Frost, C.D., Barnes, C.G., Prestvik, T. \& Nordgulen, Ø. 2014: Tectonic reconstruction and sediment provenance of a fartravelled oceanic nappe, Helgeland Nappe Complex, west-central Norway. Geological Society of London Special Publications 390, 583602. https://doi.org/10.1144/SP390.3.

Nordgulen, O., Braathen, A., Corfu, F., Osmundsen, P.T. \& Husmo, T. 2002: Polyphase kinematics and geochronology of the lateCaledonian Kollstraumen detachment, north-central Norway. Norsk geologisk tidsskrift 82, 299-316.

O'Driscoll, B., Walker, R.J., Day, J.M., Ash, R.D. \& Daly, J.S. 2015: Generations of Melt Extraction, Melt-Rock Interaction and HighTemperature Metasomatism Preserved in Peridotites of the区 497 Ma Leka Ophiolite Complex, Norway. Journal of Petrology 56, 1797-1828. https://doi.org/10.1093/petrology/egv055.

Olerud, S. 1990: Undersøkelse av talk-magnesitt forekomster ved Hundøyrån på Leka. NGU Report 90.158, 16 pp.

Olesen, O., Brönner, M., Ebbing, J., Gellein, J., Gernigon, L., Koziel, J., Lauritsen, T., Myklebust, R., Pascal, C. \& Sand, M. 2010: New aeromagnetic and gravity compilations from Norway and adjacent areas: methods and applications. In Vining, B.A. \& Pickering, S.C. (eds.): Geological Society of London, Petroleum Geology Conference series 7, Geological Society of London, pp. 559-586. https://doi.org/10.1144/0070559.

Olesen, O., Barnawal, V., Brönner, M., Dalsegg, E., Dumais, M.-A., Gellein, J., Gernigon, L., Heldal, T., Larsen, B.E., Lauritsen, T., Lutro, O., Maystrenko, Y., Nasuti, A., Roberts, D., Rueslåtten, H., Rønning, J.S., Slagstad, T., Solli, A. \& Stampolidis, A. 2015: Coop Phase 2 Crustal Onshore-Offshore Project. NGU Report 2015.063, 410 pp.

Pedersen, R. \& Furnes, H. 1991: Geology, magmatic affinity and geotectonic environment of some Caledonian ophiolites in Norway. Journal of Geodynamics 13, 183-203. https://doi.org/10.1016/0264-3707(91)90038-G.

Pedersen, R., Furnes, H. \& Dunning, G. 1988: Some Norwegian ophiolite complexes reconsidered. Norges geologiske undersøkelse Special Publication 3, 80-85.

Pedersen, R.B., Furnes, H., Prestvik, T., Barnes, C.G. \& Roberts, D. 2011: Leka, bedrock geology map 1725 IV, scale 1:50,000, Norges geologiske undersøkelse.

Plümper, O., Piazolo, S. \& Austrheim, H. 2012: Olivine Pseudomorphs after Serpentinized Orthopyroxene Record Transient Oceanic Lithospheric Mantle Dehydration (Leka Ophiolite Complex, Norway). Journal of Petrology 53, 1943-1968.

https://doi.org/10.1093/petrology/egs039.

Pozzi, J., Westphal, M., Girardeau, J., Besse, J., Zhou, Y.X., Chen, X.Y. \& Xing, L.S. 1984: Paleomagnetism of the Xigaze ophiolite and flysch (Yarlung Zangbo suture zone, southern Tibet): latitude and direction of spreading. Earth and Planetary Science Letters 70, 383394. https://doi.org/10.1016/0012-821X(84)90022-0.
Prestvik, T. 1972: Alpine-type mafic and ultramafic rocks of Leka, Nord-Trøndelag. Norges geologiske undersøkelse 273, 23-34.

Prestvik, T. 1980: The Caledonian ophiolite complex of Leka, north central Norway. In Panayioutou, A. (ed.): Ophiolites, Proceedings of the International Ophiolite Symposium, Cyprus, pp. 555-566.

Prestvik, T. 1985: Origin of the volcanic Storøya Group, Leka. Results from new geochemical investigations. Norsk geologisk tidsskrift 66, 237-239.

Prestvik, T. \& Roaldset, E. 1978: Rare earth element abundances in Caledonian metavolcanics from the island of Leka, Norway. Geochemical Journal 12, 89-100.

https://doi.org/10.2343/geochemj.12.89.

Salapare, R.C., Dimalanta, C.B., Ramos, N.T., Manalo, P.C., FaustinoEslava, D.V., Queaño, K.L. \& Yumul Jr., G.P. 2015: Upper crustal structure beneath the Zambales Ophiolite Complex, Luzon, Philippines inferred from integrated gravity, magnetic and geological data. Geophysical Journal International 201, 1522-1533. https://doi.org/10.1093/gji/ggv094.

Schouenborg, B.E. 1988: U/Pb-zircon datings of Caledonian cover rocks and cover-basement contacts, northern Vestranden, central Norway. Norsk Geologisk Tidsskrift 68, 75-87.

Sindre, A. \& Pedersen, R.-B. 1990: Gravimetrisk undersøkelse av Leka ofiolittkompleks. Norges geologiske undersøkelse Report 90.152, 20 pp.

Slagstad, T., Pin, C., Roberts, D., Kirkland, C.L., Grenne, T., Dunning, G., Sauer, S. \& Andersen, T. 2014: Tectonomagmatic evolution of the Early Ordovician suprasubduction-zone ophiolites of the Trondheim Region, Mid-Norwegian Caledonides. Geological Society of London Special Publications 390, 541-561. https://doi.org/10.1144/SP390.11.

Spicer, B., Morris, B., Ugalde, H., Slavinski, H. \& Skulski, T. 2010: Structure of the Betts Cove Ophiolite Complex beneath the western margin of Notre Dame Bay, Newfoundland. Canadian Journal of Earth Sciences 47, 181-198. https://doi.org/10.1139/E09-069.

Sturt, B.A. \& Ramsay, D.M. 1994: The structure and regional setting of the Skei Group, Leka, north-central Norway. Norges geologiske undersøkelse Bulletin 426, 31-46.

Taylor, G. 1988: A palaeomagnetic study of a Caledonian ophiolite. Geophysical Journal International 94, 157-166.

https://doi.org/10.1111/j.1365-246X.1988.tb03435.x.

Titus, S., Fossen, H., Pedersen, R., Vigneresse, J. \& Tikoff, B. 2002: Pull-apart formation and strike-slip partitioning in an obliquely divergent setting, Leka Ophiolite, Norway. Tectonophysics 354, 101119. https://doi.org/10.1016/S0040-1951(02)00293-7.

Toft, P.B., Arkani-Hamed, J. \& Haggerty, S.E. 1990: The effects of serpentinization on density and magnetic susceptibility: a petrophysical model. Physics of the Earth and Planetary Interiors 65, 137-157. https://doi.org/10.1016/0031-9201(90)90082-9. 